\title{
Characterization of Thermochemical and Thermomechanical Properties of Eyjafjallajökull Volcanic Ash Glass
}

\author{
Rebekah I. Webster ${ }^{1} \mathbb{D}$, Narottam P. Bansal ${ }^{2} \mathbb{D}$, Jonathan A. Salem ${ }^{2}$, Elizabeth J. Opila ${ }^{1}$ and \\ Valerie L. Wiesner ${ }^{3, *(\mathbb{D})}$ \\ 1 Materials Science and Engineering Department, University of Virginia, Charlottesville, VA 22903, USA; \\ riw5pv@virginia.edu (R.I.W.); ejo4n@virginia.edu (E.J.O.) \\ 2 Materials and Structures Division, NASA Glenn Research Center, Cleveland, OH 44135, USA; \\ narottam.p.bansal@nasa.gov (N.P.B.); jonathan.a.salem@nasa.gov (J.A.S.) \\ 3 Advanced Materials and Processing Branch, NASA Langley Research Center, Hampton, VA 23681, USA \\ * Correspondence: valerie.l.wiesner@nasa.gov; Tel.: +1-757-864-4384; Fax: +1-757-864-8312
}

Received: 23 December 2019; Accepted: 19 January 2020; Published: 23 January 2020

check for updates

\begin{abstract}
The properties of a volcanic ash glass obtained from the Eyjafjallajökull eruption of 2010 were studied. Crystallization experiments were carried out on bulk and powdered glass samples at temperatures between 900 and $1300{ }^{\circ} \mathrm{C}$. Iron oxides, $\mathrm{Fe}_{3} \mathrm{O}_{4}$ and $\mathrm{Fe}_{2} \mathrm{O}_{3}$, and a silicate plagioclase, $(\mathrm{Na}, \mathrm{Ca})(\mathrm{Si}, \mathrm{Al})_{4} \mathrm{O}_{8}$, were observed. Bulk samples remained mostly amorphous after up to $40 \mathrm{~h}$ at temperature. Powdered glass samples showed increased crystallinity after heat treatment compared to bulk samples. The average coefficient of thermal expansion of the glass was $7.00 \times 10^{-6} \mathrm{~K}^{-1}$ over 25-720 ${ }^{\circ} \mathrm{C}$. The Vickers hardness of the glass was 6-7 GPa and the indentation fracture toughness, 1-2 MPa $\sqrt{ } \mathrm{m}$ Values for density, elastic modulus, and Poisson's ratio were $2.52 \mathrm{~g} / \mathrm{cm}^{3}, 75 \mathrm{GPa}$, and 0.24 , respectively. The viscosity of the glass was determined experimentally and compared to three common models from the literature. The implications for the deposition of volcanic ash on hot section components of aircraft turbine engines are discussed.
\end{abstract}

Keywords: CMAS; EBCs; TBCs; volcanic ash; crystallization; thermal expansion; hardness; indentation fracture toughness; viscosity

\section{Introduction}

Particulates comprised of mainly calcium, magnesium, aluminum, and silicon oxides $\left(\mathrm{CaO}-\mathrm{MgO}-\mathrm{Al}_{2} \mathrm{O}_{3}-\mathrm{SiO}_{2}\right.$ or $\left.\mathrm{CMAS}\right)$ stand as a challenge in the development of coating systems for next-generation aircraft turbine engines. CMAS originates as siliceous debris, such as sand, volcanic ash, or runway dust, which can be ingested into the turbine on takeoff, landing, or during flight and deposit on hot-section components [1,2]. CMAS melts at $\sim 1200{ }^{\circ} \mathrm{C}$ and can infiltrate the protective barrier coatings (thermal and environmental barrier coatings, T/EBCs) needed for engine components.

Currently, superalloy components can reach a maximum temperature of $\sim 1200-1300{ }^{\circ} \mathrm{C}$ due to the presence of a thermal barrier coating (TBC) which acts as a thermally protective topcoat [3]. Silicon carbide ( $\mathrm{SiC}$ )-based ceramic matrix composites (CMCs) are proposed to replace some conventional Ni-base superalloys as turbine engine materials due to their higher operating temperatures and lighter weight, resulting in increased efficiency [4]. EBCs are required as a topcoat for CMCs to prevent thermally grown silicon oxide $\left(\mathrm{SiO}_{2}\right)$ from volatilizing in water vapor, a species resulting from the combustion of jet fuel in the engine. In addition to stability in water vapor and high-temperature environments, among other requirements [5], EBCs must be resistant to CMAS attack. The target 
operating temperature for CMCs approaches $1500^{\circ} \mathrm{C}$ [6]. The temperatures experienced by both T/EBC systems are typically above CMAS melting temperatures [7].

It has been proposed in the literature that inducing crystallization of CMAS at the T/EBC-melt interface is a viable strategy in mitigating CMAS attack by limiting the extent of glass ingress $[8,9]$. Many studies have been conducted on different coating materials wherein the ability of the T/EBC to promote crystallization of CMAS was probed and the evolution of coating/glass phases was monitored as a function of temperature and/or time [8,10-13]. Conversely, few reports have isolated the crystallization behavior of CMAS alone. CMAS composition can vary widely, depending on its source and location [14]. As such, the intrinsic properties of these glasses may also be expected to differ. In addition to crystallization behavior, CMAS composition influences its melting temperature and viscosity, both important parameters when considering coating infiltration. Mechanical properties (i.e., coefficient of thermal expansion, hardness, toughness) of CMAS can also vary and are required to fully describe coating degradation.

Zaleski et al. used differential scanning calorimetry (DSC) to probe the melting and crystallization behavior of ternary CAS, CMAS, and Fe-containing CFAS and CMFAS synthetic deposits [15]. In general, it appeared that most of the melts under study were resistant to crystallization upon cooling at $10^{\circ} \mathrm{C} / \mathrm{min}$. This behavior was most prominent in CAS compositions. The addition of $\mathrm{Fe}$, however, promoted the crystallization of phases including hematite $\left(\mathrm{Fe}_{2} \mathrm{O}_{3}\right)$, esseneite $(\mathrm{CaFeAlSiO})$, and Ca-ferrite $\left(\mathrm{CaFe}_{2} \mathrm{O}_{4}\right)$, as indicated by $x$-ray diffraction (XRD). Isothermal DSC measurements on a $\mathrm{Ca}_{13} \mathrm{Fe}_{10} \mathrm{Al}_{18} \mathrm{Si}_{59}(\mathrm{~mol} \%)$ glass showed significantly increased crystallization kinetics compared to the ternary $\mathrm{Ca}_{15} \mathrm{Al}_{20} \mathrm{Si}_{65}$ having a similar Ca:Si ratio and $\mathrm{Al}$ content. The presence of Fe is likely important when considering volcanic ash glasses, as bulk compositions have been previously reported with up to 16 at \% Fe [16].

The objective of the current work was to characterize the intrinsic properties of a volcanic ash glass containing CMAS and $\mathrm{Fe}_{2} \mathrm{O}_{3}, \mathrm{TiO}_{2}, \mathrm{Na}_{2} \mathrm{O}$, and $\mathrm{K}_{2} \mathrm{O}$. The crystallization behavior of the volcanic ash glass was determined in bulk and powdered form. Thermal and mechanical properties including melting $\left(T_{\mathrm{m}}\right)$ and glass transition $\left(T_{\mathrm{g}}\right)$ temperature, coefficient of thermal expansion (CTE), hardness, indentation fracture toughness, elastic modulus $(E)$, and Poisson's ratio $(v)$ were also measured. Glass viscosity was determined experimentally and compared to calculated values based on composition using several viscosity models described in the literature. The intrinsic properties of the volcanic ash glass were compared to those of previously investigated synthetic sand and desert sand CMAS glasses [17-19]. The significance of results with respect to T/EBC design are discussed.

\section{Experimental Procedure}

Ash obtained from the 2010 eruption of Iceland's Eyjafjallajökull volcano was melted at $1500{ }^{\circ} \mathrm{C}$ for $1 \mathrm{~h}$ in a platinum crucible followed by quenching in water. The composition of the resulting glass was determined by inductively coupled plasma atomic emission spectroscopy (ICP-AES) performed by a commercial test laboratory and can be found in Table 1 . Table 1 also includes the composition of a synthetic sand glass $[17,18]$ and a desert sand glass [19] for comparison.

Differential thermal analysis (DTA) was carried out using a Netzsch STA 409 (Burlington, MA, USA) on bulk and powder glass samples to determine melting and crystallization behavior. Scans were performed in flowing air from room temperature to $1500^{\circ} \mathrm{C}$ at a ramp rate of $10{ }^{\circ} \mathrm{C} / \mathrm{min}$. A platinum pan was used to contain each sample. Prior to each run, a background scan was performed under identical conditions and was subsequently subtracted from the sample scan.

Isothermal heat treatments were carried out in a stagnant air box furnace on bulk glass pieces weighing approximately $250-350 \mathrm{mg}$. Samples were placed on a platinum foil and were either exposed for 1, 10, or $20 \mathrm{~h}$ at 900 and $1000{ }^{\circ} \mathrm{C}$ (low-temperature furnace; Neytech Vulcan 3-550; Bloomfield, NJ, USA) or for 1, 10, 20, or $40 \mathrm{~h}$ at 1100, 1150, 1200, and $1300^{\circ} \mathrm{C}$ (high-temperature furnace; Carbolite HTF 18/27; Hope Valley, UK). Samples were cooled at either $10^{\circ} \mathrm{C} / \mathrm{min}$ or quenched in air. Some experiments were carried out using glass powder instead of bulk specimens; in these cases, bulk pieces weighing 250-350 mg were ground with mortar and pestle to a fine grit prior to exposure. After heat treatment, 
samples were either crushed for x-ray diffraction (XRD) phase analysis (Bruker D8 Advance; Billerica, MA, USA) or mounted and polished in cross-section for imaging by scanning electron microscopy (SEM-Phenom-World Phenom Pro; Eindhoven, The Netherlands). Mounted and polished specimens were coated with a thin layer of platinum prior to imaging. Quantitative XRD was performed by mixing 20-25 wt \% $\alpha-\mathrm{Al}_{2} \mathrm{O}_{3}$ (corundum) with the powdered samples after heat treatment. Powders were mixed thoroughly by grinding with a mortar and pestle. Quantitative XRD scans were run from a $2 \theta$ of $10^{\circ}$ to $120^{\circ}$ with a step size of $0.02^{\circ}$ and a step time of $2.5 \mathrm{~s} / \mathrm{step}$. Sample peaks were referenced to the $\mathrm{Al}_{2} \mathrm{O}_{3}$ standard in the Whole Pattern Fitting (WPF) module of Jade 2010 software from Materials Data Inc. (MDI; Livermore, CA, USA).

Table 1. Composition (in mol \% and wt \%, determined by inductively coupled plasma atomic emission spectroscopy-ICP-AES) of the volcanic ash glass prepared in this study compared to previously investigated synthetic sand and desert sand glasses [17-19]. Estimated uncertainty for values in the range of $1.0-3.0 \%= \pm 10 \%$ of actual value, for values in the range of $3.0-10.0 \%= \pm 5 \%$ of actual value, for values in the range of $10.0-25.0 \%= \pm 2 \%$ of actual value, for values in the range of $25.0-75.0 \%=$ $\pm 1 \%$ of actual value.

\begin{tabular}{|c|c|c|c|c|c|c|c|c|c|c|}
\hline & & $\mathrm{CaO}$ & $\mathrm{MgO}$ & $\mathrm{Al}_{2} \mathrm{O}_{3}$ & $\mathrm{SiO}_{2}$ & $\mathrm{Fe}_{2} \mathrm{O}_{3}$ & $\mathrm{TiO}_{2}$ & $\mathrm{Na}_{2} \mathrm{O}$ & $\mathrm{K}_{2} \mathrm{O}$ & Trace Oxides \\
\hline \multirow{2}{*}{ Volcanic ash glass } & $\mathrm{mol} \%$ & 6.2 & 4.2 & 10.1 & 67.5 & 4.4 & 1.4 & 5.0 & 1.2 & - \\
\hline & wt $\%$ & 4.9 & 2.4 & 14.6 & 57.3 & 10.0 & 1.6 & 4.4 & 1.6 & bal. \\
\hline \multirow{2}{*}{ Synthetic sand glass } & $\mathrm{mol} \%$ & 23.3 & 6.4 & 3.1 & 62.5 & 0.04 & - & 4.1 & 0.5 & - \\
\hline & wt $\%$ & 21.9 & 4.3 & 5.4 & 63 & 0.1 & - & 4.3 & 0.8 & bal. \\
\hline \multirow{2}{*}{ Desert sand glass } & $\mathrm{mol} \%$ & 27.8 & 4 & 5 & 61.6 & 0.6 & - & - & 1 & - \\
\hline & wt $\%$ & 25.2 & 2.6 & 8.2 & 59.8 & 1.6 & - & - & 1.5 & bal. \\
\hline
\end{tabular}

Sample discs were prepared for mechanical testing and dilatometry using a Centorr mini hot press (Nashua, NH, USA). Glass powder was loaded into a graphite die and treated at $600{ }^{\circ} \mathrm{C}$ and $2 \mathrm{ksi}(13.8 \mathrm{MPa})$ for $10 \mathrm{~min}$ under vacuum. Specimens were cooled to room temperature at a rate of $10{ }^{\circ} \mathrm{C} / \mathrm{min}$ after the applied pressure was removed. Graphite foil was used to cover the die pieces in contact with the glass during pressing, and any residual foil was removed from sample surfaces by polishing.

Glass density was calculated from the measured mass and volume of the hot-pressed glass disc. The impulse excitation method described in ASTM C1259 [20] was used to determine the elastic modulus and Poisson's ratio of the glass at room temperature. An Audio Technica ATM350 condenser microphone with an M-Audio DMP preamplifier was used to acoustically measure and amplify the natural frequency of the glass disc upon mechanical excitation in the desired mode. The acoustic signal acquisition hardware and Sound \& Vibration Toolset software from National Instruments (Austin, TX, USA) were used to determine the disc's frequency, which was used to calculate the elastic modulus and Poisson's ratio.

A Struer's DuraScan (Cleveland, OH, USA) was used to apply a Vickers diamond indent onto the glass disc surface, which was polished according to ASTM C1327-08 [21]. Three indentations were made on the polished disc at each individual load of 1.96, 2.94, 4.9, and $9.8 \mathrm{~N}$ applied for $15 \mathrm{~s}$. The diagonal $(2 a)$ and crack $(2 c)$ lengths of each indentation were measured.

A glass bar with length of $2.5 \mathrm{~cm}$ was evaluated using a Netzsch differential dilatometer model $402 \mathrm{C}$ (Burlington, MA, USA) interfaced with a computerized data acquisition and analysis system to measure the glass transition temperature $\left(T_{\mathrm{g}}\right)$, softening point $\left(T_{\mathrm{d}}\right)$, and linear coefficient of thermal expansion (CTE; $\alpha$ ). The glass bar was heated at a rate of $5^{\circ} \mathrm{C} / \mathrm{min}$ in the air from room temperature to $1000^{\circ} \mathrm{C}$.

Viscosity measurements were performed using an Orton RSV-1600 viscometer furnace setup (Westerville, OH, USA) equipped with a Brookfield (Middleboro, MA, USA) HA-DV2T viscosity measuring unit and platinum spindle. A $50 \mathrm{~mL}$ platinum crucible was filled with approximately $80 \mathrm{~g}$ 
of volcanic ash glass for a molten glass volume of approximately $30 \mathrm{~mL}$. Viscosity measurements were performed between about 1300 and $1500{ }^{\circ} \mathrm{C}$. The viscometer furnace was held at $1500{ }^{\circ} \mathrm{C}$ for at least $20 \mathrm{~min}$ to equilibrate the melt. Two methods were utilized for collecting data. In the first, the spindle was lowered into the melt and allowed to rotate continuously as the furnace cooled at $2{ }^{\circ} \mathrm{C} / \mathrm{min}$. Viscosity data was collected during cooling. In the second, the spindle was lowered into the melt and allowed to rotate. The furnace was cooled at $50{ }^{\circ} \mathrm{C}$ intervals and held at each temperature for $20 \mathrm{~min}$. The viscosity of the glass was determined at each temperature after a stable reading was obtained.

The viscosity of the glass melt was determined by measuring the percent spindle torque required to maintain the spindle rotation at the desired speed. The viscosity of the melt ( $\eta$; in centipoise) is related to the spindle torque $(\tau)$ and rotational speed (RPM) by the following equation, found in the Orton RSV-1600 instrument manual:

$$
\eta=\frac{100}{\mathrm{RPM}} \times \mathrm{TK} \times \mathrm{SMC} \times \tau
$$

where TK and SMC are the viscometer torque constant and the spindle multiplier constant, respectively. These values were provided in the viscometer software. The viscosity of a borosilicate glass standard (NIST SRM 717a, Sigma Aldrich; St. Louis, MO, USA) was determined experimentally between $1000-1325^{\circ} \mathrm{C}$, confirming that the supplied constants gave accurate data in the temperature region of interest (Figure 1). The borosilicate glass standard was not run above $1325^{\circ} \mathrm{C}$ due to volatility concerns. The calculated viscosity curve (Figure 1) was determined using viscosity constants provided by NIST.

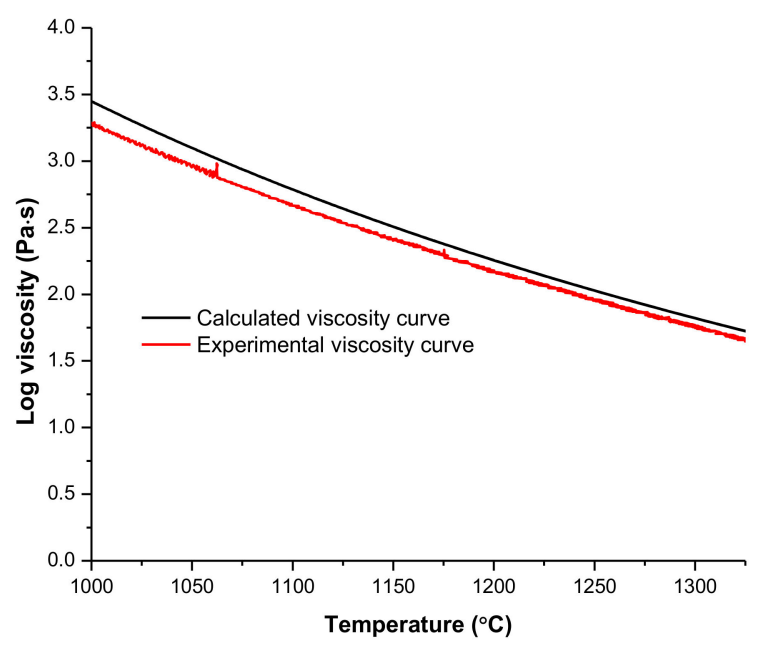

Figure 1. Calculated and experimental viscosity curves for a borosilicate glass standard.

\section{Results}

\subsection{Crystallization Behavior-DTA}

DTA heating and cooling curves at a ramp rate of $10^{\circ} \mathrm{C} / \mathrm{min}$ are given in Figure 2 for the bulk and powdered glass. A list of observed DTA thermal events, described for bulk and powdered glasses, is given in Table 2. On heating, the bulk glass exhibited exothermic peaks at approximately 900 (Figure $\left.2-1_{\mathrm{B}}\right)$ and $1100^{\circ} \mathrm{C}\left(2_{\mathrm{B}}\right)$, which corresponded to crystallization. Each peak is likely attributed to the crystallization of a distinct phase. There appeared to be a melt endotherm with a peak temperature of approximately $1350^{\circ} \mathrm{C}$; however, the peak itself was very broad. A dip in the baseline was evident at about $1050{ }^{\circ} \mathrm{C}\left(3_{\mathrm{B}}\right)$, suggesting that this glass started to melt around $1050{ }^{\circ} \mathrm{C}$ and might not have a distinct melting temperature. Indeed, in separate box furnace experiments glass specimens were observed to bead by $1100{ }^{\circ} \mathrm{C}$ and wet the platinum holder substrate by $1150^{\circ} \mathrm{C}$. Bulk glass specimens after heat treatment at 1100 and $1150{ }^{\circ} \mathrm{C}$ are shown in Figure 3. Bulk glass heat treated at $1300{ }^{\circ} \mathrm{C}$ for $1 \mathrm{~h}$ and air quenched was almost entirely amorphous by XRD analysis, suggesting that by this temperature, 
the glass was nearly completely molten. On cooling, an exothermic peak was also observed around $900{ }^{\circ} \mathrm{C}\left(4_{\mathrm{B}}\right)$ suggesting that a similar phase that crystallized around $900{ }^{\circ} \mathrm{C}$ on heating $\left(1_{\mathrm{B}}\right)$ might have also evolved upon cooling at $10^{\circ} \mathrm{C} / \mathrm{min}$.

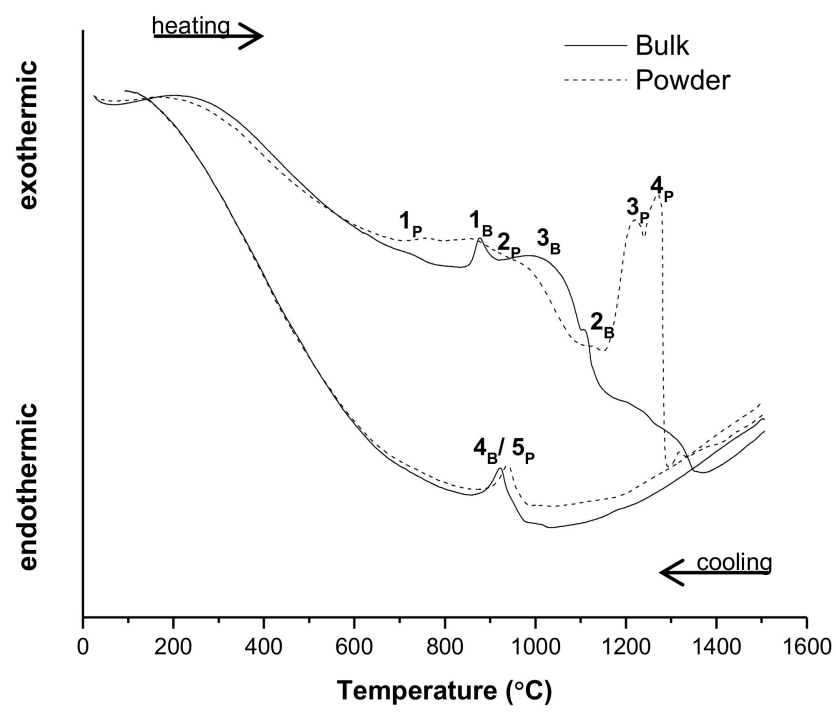

Figure 2. Bulk (bold line) and powder (dashed line) volcanic ash glass differential thermal analysis (DTA) curves with a ramp rate of $10^{\circ} \mathrm{C} / \mathrm{min}$. Labels $1_{\mathrm{B}}, 2_{\mathrm{B}}, 1_{\mathrm{P}}, 2_{\mathrm{P}}$, and $3_{\mathrm{P}}$ correspond to crystallization in the bulk (B) and powder (P) samples on heating. Labels $3_{\mathrm{B}}$ and $4_{\mathrm{P}}$ show the onset of melting. Labels $4_{\mathrm{B}}$ and $5_{\mathrm{P}}$ indicate solidification of molten glass upon cooling.

Table 2. List of DTA thermal events presented in Figure 2 for the volcanic ash glass.

\begin{tabular}{lcccc}
\hline & Bulk & Approximate Temperature $\left({ }^{\circ} \mathrm{C}\right)$ & Powder & $\begin{array}{c}\text { Approximate } \\
\text { Temperature }\left({ }^{\circ} \mathrm{C}\right)\end{array}$ \\
\hline On heating & & & & \\
\hline Onset Melting (endo) & $3_{\mathrm{B}}$ & $1050{ }^{\circ} \mathrm{C}$ (peak melting at $\left.1350{ }^{\circ} \mathrm{C}\right)$ & $4_{\mathrm{P}}$ & $950-1000{ }^{\circ} \mathrm{C}$ \\
Crystallization (exo) & $1_{\mathrm{B}}, 2_{\mathrm{B}}$ & $900,1100{ }^{\circ} \mathrm{C}$ & $1_{\mathrm{P}}, 2_{\mathrm{P}}, 3_{\mathrm{P}}$ & $900,1225,1275{ }^{\circ} \mathrm{C}$ \\
\hline On cooling & & & & \\
\hline Crystallization (exo) & $4_{\mathrm{B}}$ & $900{ }^{\circ} \mathrm{C}$ & $5_{\mathrm{P}}$ & $900{ }^{\circ} \mathrm{C}$ \\
\hline
\end{tabular}

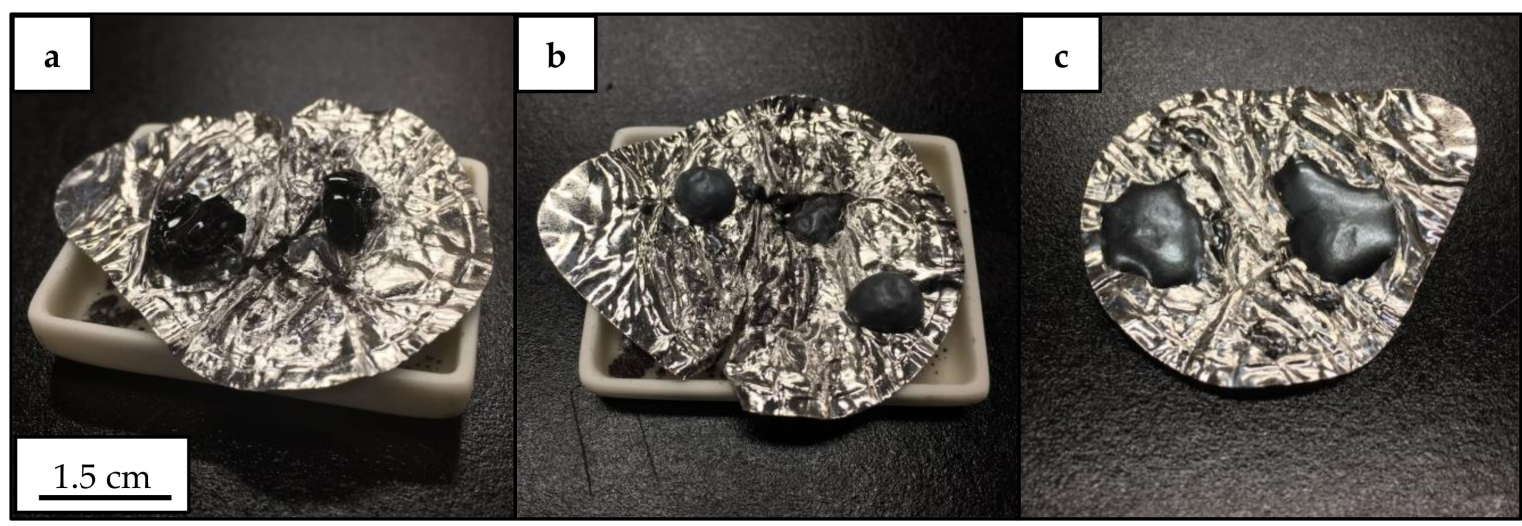

Figure 3. Bulk volcanic ash glass samples before heat treatment (a) and after heat treatment at 1100 (b) and $1150{ }^{\circ} \mathrm{C}$ (c). The solidified glass samples are the dark droplets on Pt foil.

The heating curve for powdered glass was quite different from that seen for the bulk, as shown in Figure 2. There was a broad exothermic hump that centered around $900{ }^{\circ} \mathrm{C}$. This peak was not as distinct as for the bulk glass and had a comparatively lower onset temperature $\left(1_{\mathrm{P}}\right)$. In addition, instead 
of having a second exothermic peak around $1100{ }^{\circ} \mathrm{C}$, there were two very large peaks at approximately $1225\left(2_{\mathrm{P}}\right)$ and $1275^{\circ} \mathrm{C}\left(3_{\mathrm{P}}\right)$. It is somewhat difficult to distinguish background information from actual thermal events for this curve, however, the melting behavior appeared similar to that for the bulk-the onset (4P) and peak melting temperatures being shifted to slightly lower values. On cooling, there was an exothermic peak at approximately $900{ }^{\circ} \mathrm{C}\left(5_{\mathrm{P}}\right)$, echoing that observed for the bulk sample.

\subsection{Crystallization Behavior-Box Furnace Experiments}

XRD plots for bulk glass pieces treated for $1 \mathrm{~h}$ at $900-1200{ }^{\circ} \mathrm{C}$ can be seen in Figure 4 . All scans were collected for samples after being heated and cooled at $10{ }^{\circ} \mathrm{C} / \mathrm{min}$. XRD patterns for specimens that were placed in and removed from the furnace at temperature (i.e., quenched in air) did not show differences in phase or amount of phase present when compared to samples that were ramped to and from temperature. Consequently, XRD results for quenched specimens were excluded from the rest of this report. In Figure 4, the XRD scan for glass not exposed to temperature is also shown (labeled "Control") for comparison. Only two phases were discerned- $\mathrm{Fe}_{3} \mathrm{O}_{4}$ (magnetite) and $\mathrm{Fe}_{2} \mathrm{O}_{3}$ (hematite). After heat treatment at 900 and $1000^{\circ} \mathrm{C}$, broad, shallow peaks for magnetite were present, but the glass appeared to have remained mostly amorphous. At 1100,1150 , and $1200{ }^{\circ} \mathrm{C}$, the peak for magnetite appeared larger and sharper. At 1150 and $1200{ }^{\circ} \mathrm{C}$, the $100 \%$ intensity peak for hematite began to emerge.

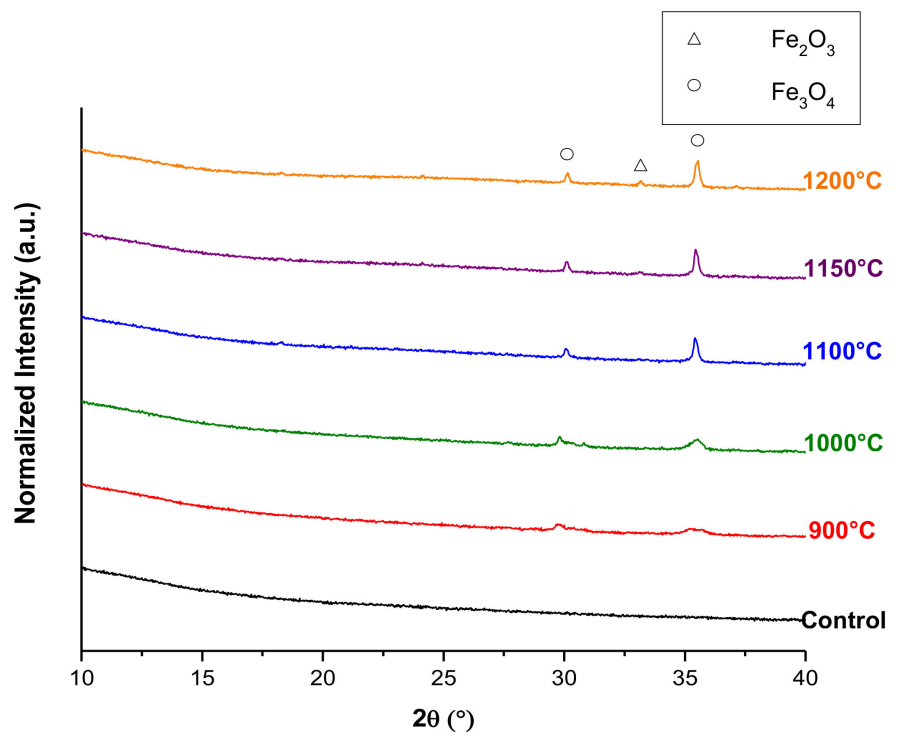

Figure 4. XRD plots for bulk volcanic ash glass heat treated for $1 \mathrm{~h}$ at $900,1000,1100,1150$, and $1200{ }^{\circ} \mathrm{C}$ (ramp rate $10^{\circ} \mathrm{C} / \mathrm{min}$ ). The "Control" spectrum is for volcanic ash glass not exposed to temperature.

As the amount of time held at temperature was increased for $1100-1200^{\circ} \mathrm{C}$ treatments, the magnetite was converted to hematite (Table 3). The transition from magnetite to hematite occurred more rapidly as the temperature increased, such that there was a higher relative amount of hematite after $10 \mathrm{~h}$ at $1200{ }^{\circ} \mathrm{C}$ compared to after $10 \mathrm{~h}$ at $1100{ }^{\circ} \mathrm{C}$ (Table 3). This is likely due to the enhanced diffusion of oxygen through the bulk glass at higher temperatures [22]. The reaction of $\mathrm{Fe}_{3} \mathrm{O}_{4}$ to $\mathrm{Fe}_{2} \mathrm{O}_{3}$ is given by [23]

$$
4 \mathrm{Fe}_{3} \mathrm{O}_{4}+\mathrm{O}_{2}(\mathrm{~g}) \leftrightarrow 6 \mathrm{Fe}_{2} \mathrm{O}_{3}
$$

The evolution of the microstructure of samples held at $1150{ }^{\circ} \mathrm{C}$ can be seen in Figure 5 . Energy dispersive spectroscopy (EDS) was unable to differentiate $\mathrm{Fe}_{3} \mathrm{O}_{4}$ from $\mathrm{Fe}_{2} \mathrm{O}_{3}$. The bright (by backscattered electron imaging, BSE) Fe-based precipitates appear as both faceted particulates and rod-like structures. Faceted particles are mostly submicron in size after $1 \mathrm{~h}$ at temperature but grow to a maximum diameter of approximately $10 \mu \mathrm{m}$ with increasing time. In some areas, the surface 
of the glass had a thin layer or "shell" of Fe-based particulates (somewhat visible in Figure 5c,d, more apparent in Figure 6).

Table 3. The phase composition of bulk volcanic ash glass samples after heat treatment using quantitative XRD analysis.

\begin{tabular}{ccccc}
\hline & wt \% Amorphous & $\mathbf{w t} \% \mathrm{Fe}_{3} \mathbf{O}_{4}$ & $\mathbf{w t} \% \mathrm{Fe}_{2} \mathbf{O}_{3}$ & wt \% Plagioclase \\
\hline $1100{ }^{\circ} \mathrm{C}$ & & & & \\
\hline $1 \mathrm{~h}$ & $88.7 \pm 0.1$ & $9.9 \pm 0.1$ & $1.4 \pm 0.1$ & 0.0 \\
$10 \mathrm{~h}$ & $87.8 \pm 0.2$ & $8.9 \pm 0.1$ & $1.0 \pm 0.1$ & $2.3 \pm 0.2$ \\
$20 \mathrm{~h}$ & $89.4 \pm 0.1$ & $5.9 \pm 0.1$ & $2.3 \pm 0.1$ & $2.4 \pm 0.1$ \\
$40 \mathrm{~h}$ & $81.7 \pm 0.3$ & $4.6 \pm 0.1$ & $3.0 \pm 0.1$ & $10.7 \pm 0.3$ \\
\hline $1150^{\circ} \mathrm{C}$ & & & & \\
\hline $1 \mathrm{~h}$ & $90.7 \pm 0.1$ & $8.5 \pm 0.1$ & $0.8 \pm 0.0$ & 0.0 \\
$10 \mathrm{~h}$ & $94.2 \pm 0.1$ & $2.8 \pm 0.0$ & $3.0 \pm 0.0$ & 0.0 \\
$20 \mathrm{~h}$ & $94.5 \pm 0.1$ & $1.6 \pm 0.1$ & $3.9 \pm 0.0$ & 0.0 \\
$40 \mathrm{~h}$ & $95.7 \pm 0.0$ & 0.0 & $4.3 \pm 0.0$ & 0.0 \\
\hline $1200{ }^{\circ} \mathrm{C}$ & & & & 0.0 \\
\hline $1 \mathrm{~h}$ & $90.6 \pm 0.1$ & $7.7 \pm 0.1$ & $1.8 \pm 0.1$ & 0.0 \\
$10 \mathrm{~h}$ & $95.5 \pm 0.1$ & $0.9 \pm 0.1$ & $3.6 \pm 0.0$ & 0.0 \\
\hline $20 \mathrm{~h}$ & $95.4 \pm 0.1$ & $1.4 \pm 0.0$ & $3.2 \pm 0.0$ & \\
\hline
\end{tabular}

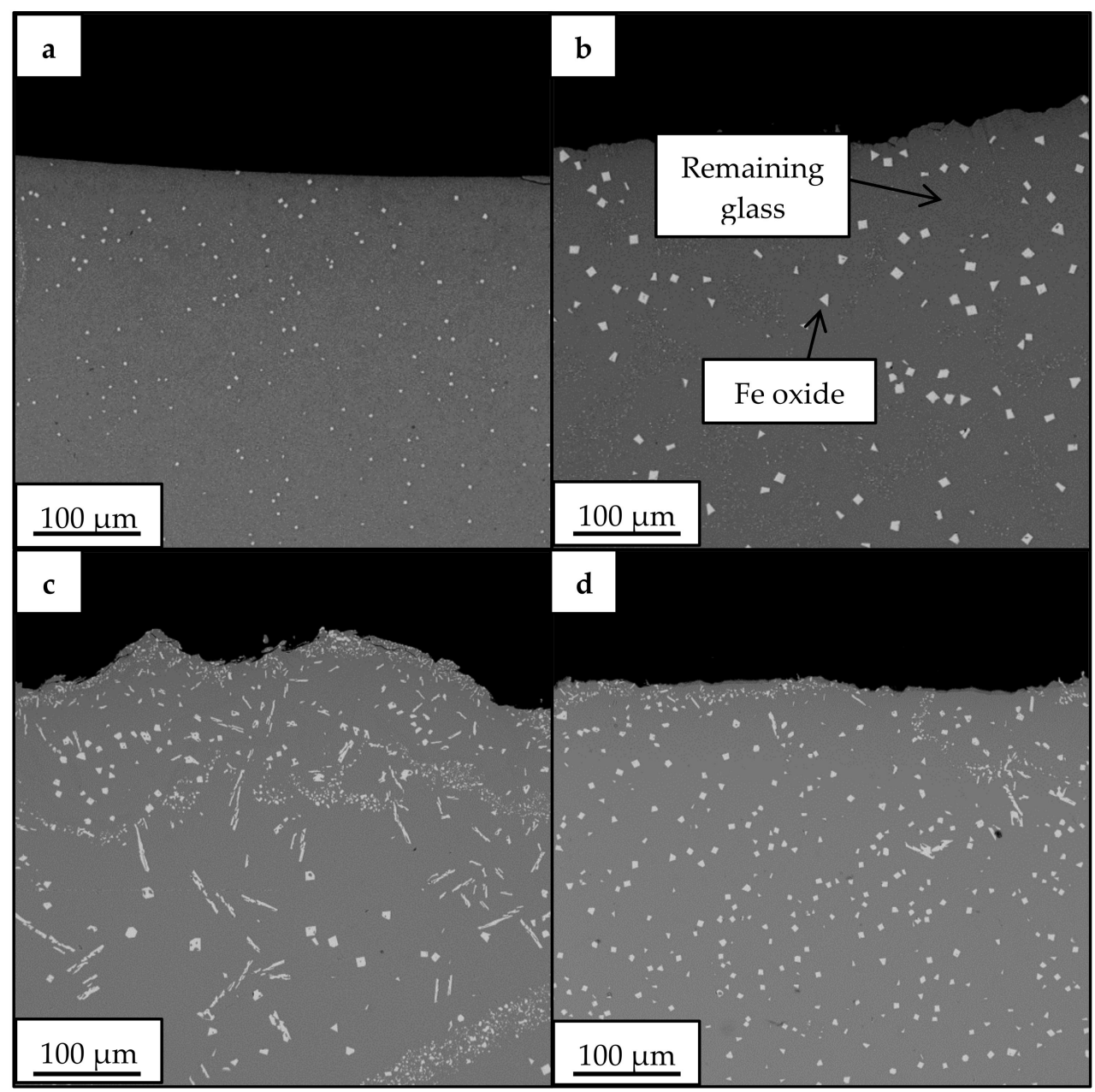

Figure 5. Cross-section backscattered electron imaging (BSE) images of bulk volcanic ash glass after exposure at $1150{ }^{\circ} \mathrm{C}$ for $1 \mathrm{~h} \mathrm{(a),} 10 \mathrm{~h}(\mathbf{b}), 20 \mathrm{~h} \mathrm{(c)}$, and $40 \mathrm{~h}(\mathbf{d})$. 


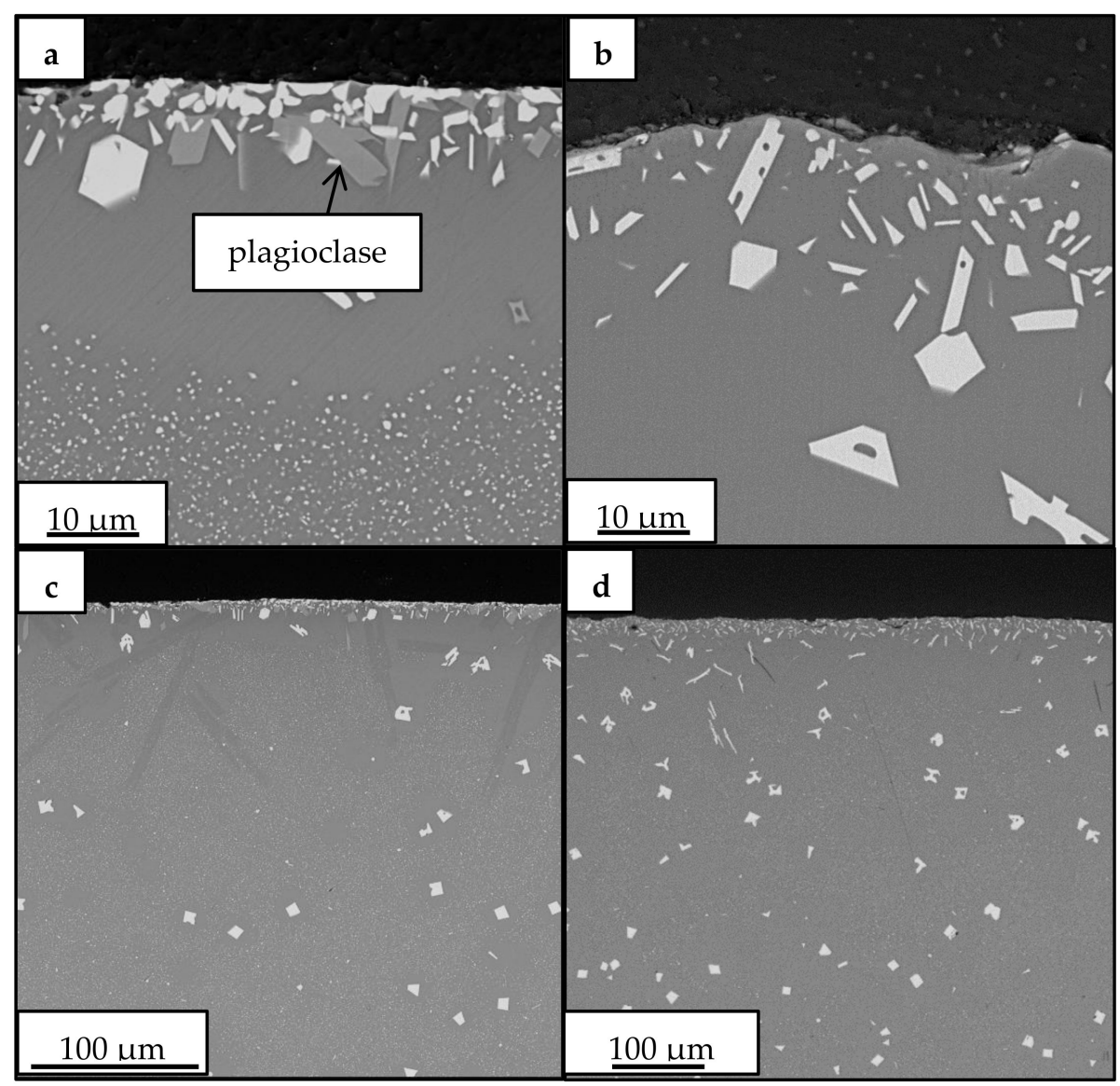

Figure 6. Cross-section BSE images for bulk volcanic ash glass samples treated at $1100(\mathbf{a}, \mathbf{c})$ and $1150{ }^{\circ} \mathrm{C}$ $(\mathbf{b}, \mathbf{d})$ for $10 \mathrm{~h}$.

At $1100{ }^{\circ} \mathrm{C}$, a third phase, likely a solid solution of anorthite $\left(\mathrm{CaAl}_{2} \mathrm{Si}_{2} \mathrm{O}_{8}\right)$ and albite $\left(\mathrm{NaAlSi}_{3} \mathrm{O}_{8}\right)$, was detected after holding for $10 \mathrm{~h}$ (see Figure 6). This phase (hereto referred to as plagioclase) may also be present in small amounts at $1000^{\circ} \mathrm{C}$.

SEM BSE cross-section images are presented in Figure 6 for samples held at 1100 and $1150{ }^{\circ} \mathrm{C}$ for $10 \mathrm{~h}$. The results given by SEM supported those of XRD. After $10 \mathrm{~h}$ at $1100^{\circ} \mathrm{C}$, there appeared to be two phases growing at the surface of the glass (Figure 6a). EDS confirmed a Fe-rich phase (lighter contrast by BSE) and a Si-rich phase (darker by BSE). Iron oxides (likely mostly $\mathrm{Fe}_{3} \mathrm{O}_{4}$ based on XRD) were also present throughout the bulk of the sample (Figure 6c) but were generally smaller than those in the $1150{ }^{\circ} \mathrm{C}$ sample (Figures $5 \mathrm{~b}$ and $6 \mathrm{~d}$ ). A thin layer of concentrated Fe precipitates can be seen at the surface of both the 1100 and $1150{ }^{\circ} \mathrm{C}$ (Figure 6c,d) samples. This "shell" is likely the $\mathrm{Fe}_{2} \mathrm{O}_{3}$ phase, as it has been previously observed in magnetite iron ore pellets oxidized at $800-1200{ }^{\circ} \mathrm{C}$ [24]. The "shell" was not always continuous across the surface of samples, which may be due to the removal of material when separating the bulk glass from its platinum substrate. As expected from XRD, no plagioclase phase was observed in the $1150{ }^{\circ} \mathrm{C}$ sample (Figure 6b).

When powdered samples were heated in the box furnace at 1100 and $1150{ }^{\circ} \mathrm{C}$, the prominent crystallized phases were $\mathrm{Fe}_{2} \mathrm{O}_{3}$ and plagioclase (Figure 7). The amounts of each phase are given in Table 4. It is expected that the increased amount of crystallized glass compared to bulk samples is due to the increased surface area of the powder.

FactSage free energy minimization calculations were performed for both the volcanic ash glass and the synthetic sand glass compositions (Table 1), using the Equilibrium Module and FToxide database, including SLAGA [25], to determine the expected phase distributions at a given temperature based on thermodynamics alone. Respective amounts of the different CMAS oxides (in mol \%, Table 1) were used as FactSage inputs. Calculations were performed at $1 \mathrm{~atm}$. As was observed experimentally, 
FactSage indicated that $\mathrm{Fe}_{2} \mathrm{O}_{3}$ and albite $\left(\mathrm{NaAlSi}_{3} \mathrm{O}_{8}\right)$ and anorthite $\left(\mathrm{CaAl}_{2} \mathrm{Si}_{2} \mathrm{O}_{8}\right)$ were among the expected phase formations. Between $900-1150{ }^{\circ} \mathrm{C}, \mathrm{SiO}_{2}, \mathrm{MgSiO}_{3}, \mathrm{KAlSi}_{3} \mathrm{O}_{8}, \mathrm{CaSiTiO}_{5}$, and $\mathrm{CaMgSi}_{2} \mathrm{O}_{6}$ (diopside) were among other phases also predicted to appear. Albite was not seen above $1050{ }^{\circ} \mathrm{C}$ and $\mathrm{Fe}_{2} \mathrm{O}_{3}$ was the only expected solid-phase above $\sim 1200^{\circ} \mathrm{C}$. The amount of the observed phases as a function of temperature is given in Figure 8. A Scheil-Gulliver cooling profile was also performed, with a start and stop temperature of 1300 and $900{ }^{\circ} \mathrm{C}$, respectively, and a step size of $25^{\circ} \mathrm{C}$. This method subtracts precipitated phase constituents from the overall glass composition as they form. At and above $1200{ }^{\circ} \mathrm{C}$, only $\mathrm{Fe}_{2} \mathrm{O}_{3}$ is expected. Below $1200{ }^{\circ} \mathrm{C}$, anorthite forms; at $\leq 1100{ }^{\circ} \mathrm{C}, \mathrm{MgSiO}_{3}$, diopside, and $\mathrm{CaSiTiO}_{5}$ appear in addition to $\mathrm{Fe}_{2} \mathrm{O}_{3}$ and anorthite. Albite is only discerned at $\leq 1000{ }^{\circ} \mathrm{C}$.

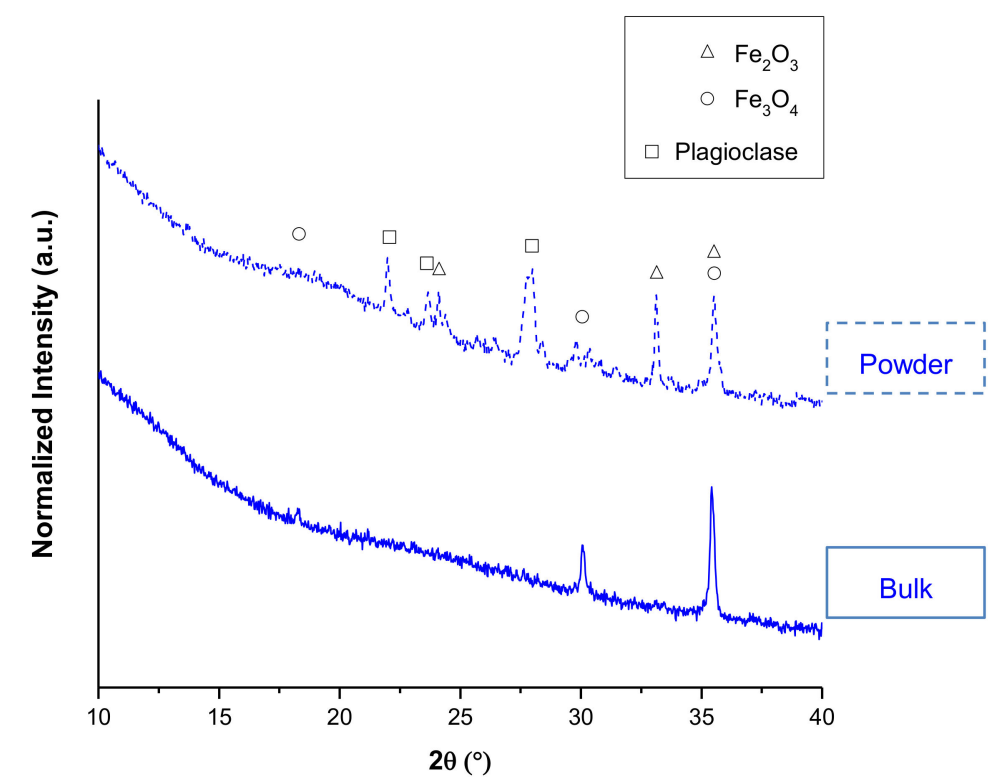

Figure 7. XRD spectra for bulk (solid line) and powder (dashed line) volcanic ash glass samples exposed to $1100^{\circ} \mathrm{C}$ for $1 \mathrm{~h}$.

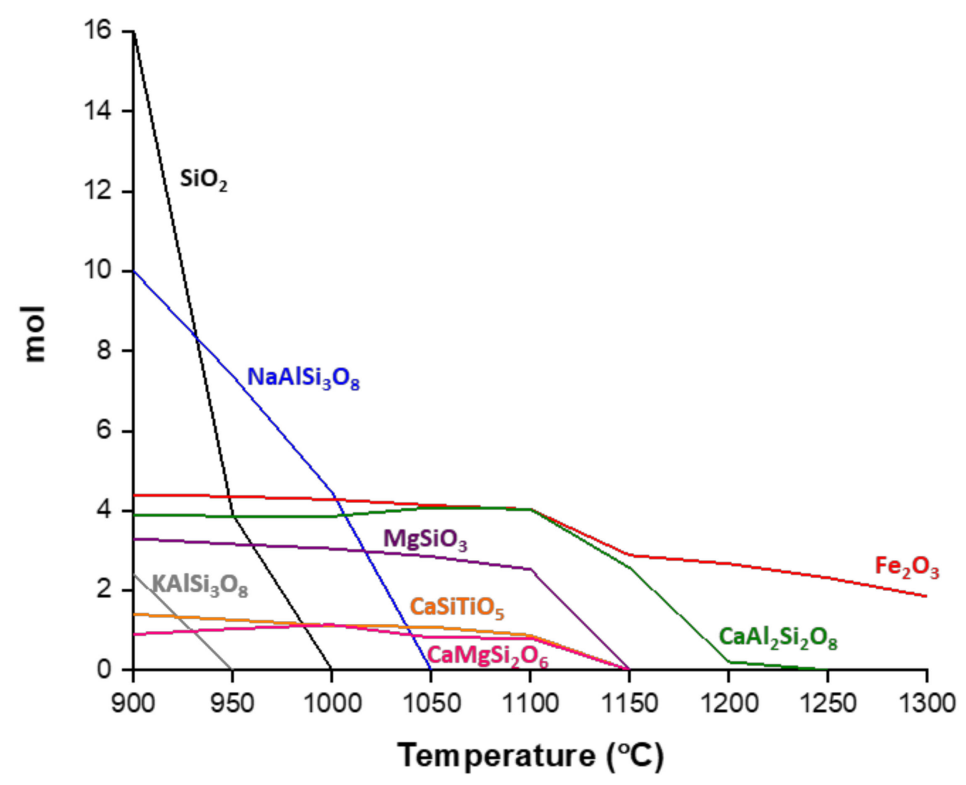

Figure 8. Expected phase formations in the volcanic ash glass as a function of temperature, calculated using the FactSage Equilibrium module. 
The same processes were performed for the synthetic sand glass. Wollastonite $\left(\mathrm{CaSiO}_{3}\right)$ and diopside were among the expected phase formations between $900-1300^{\circ} \mathrm{C}$. Other predicted phases (between $900-1000{ }^{\circ} \mathrm{C}$ ) included albite, $\mathrm{SiO}_{2}$, and $\mathrm{Na}_{2} \mathrm{Ca}_{3} \mathrm{Si}_{6} \mathrm{O}_{16}$. Figure 9 plots the expected phase formations in the synthetic sand glass as a function of temperature.

Table 4. The phase composition of powder volcanic ash glass samples after heat treatment using quantitative XRD analysis.

\begin{tabular}{ccccc}
\hline & wt \% Amorphous & $\mathbf{w t} \% \mathrm{Fe}_{3} \mathrm{O}_{4}$ & $\mathbf{w t} \% \mathrm{Fe}_{2} \mathrm{O}_{3}$ & wt \% Plagioclase \\
\hline $1100{ }^{\circ} \mathrm{C}$ & & & & \\
\hline $1 \mathrm{~h}$ & $50.6 \pm 0.5$ & $3.9 \pm 0.1$ & $7.2 \pm 0.1$ & $38.3 \pm 0.5$ \\
\hline $1150{ }^{\circ} \mathrm{C}$ & & & & \\
\hline $1 \mathrm{~h}$ & $65.5 \pm 0.3$ & $0.5 \pm 0.1$ & $7.1 \pm 0.1$ & $26.8 \pm 0.3$ \\
\hline
\end{tabular}

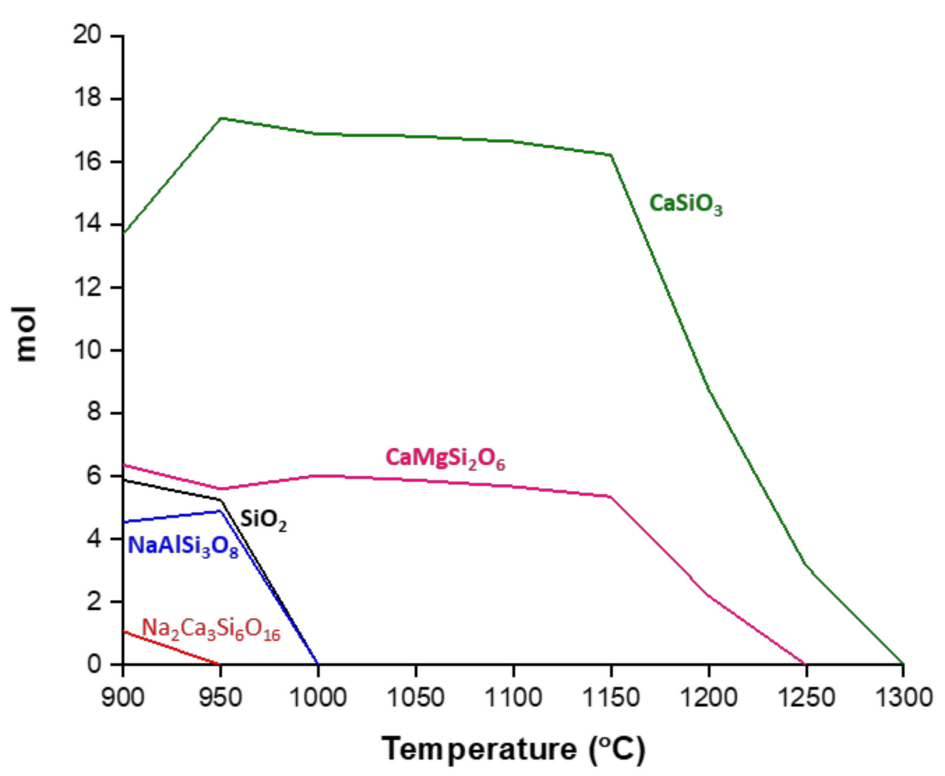

Figure 9. Expected phase formations in the synthetic sand glass as a function of temperature, calculated using the FactSage Equilibrium module.

\subsection{Thermal Behavior-Dilatometry}

Figure 10 shows the dilatometric thermal expansion curve for the hot-pressed volcanic ash glass bar heated at $5{ }^{\circ} \mathrm{C} / \mathrm{min}$ from RT to $1000^{\circ} \mathrm{C}$. Dilatometric values for the volcanic ash glass, synthetic sand glass, and desert sand glass are found in Table 5 . The $T_{\mathrm{g}}$ and $T_{\mathrm{d}}$ of the volcanic ash glass were observed to be 741 and $844{ }^{\circ} \mathrm{C}$, respectively. Comparatively, the synthetic and desert sand glasses referred to in Table 1 had reported $T_{\mathrm{g}}$ values of 694 and $706{ }^{\circ} \mathrm{C}$, respectively, and $T_{\mathrm{d}}$ values of 751 and $764^{\circ} \mathrm{C}$, respectively. The average linear CTE for the bulk volcanic ash glass was $7.00 \times 10^{-6} \mathrm{~K}^{-1}$ between $25-720^{\circ} \mathrm{C}$. This value was lower than the reported $\sim 9-10 \times 10^{-6} \mathrm{~K}^{-1}$ for the synthetic and desert sand glasses over the same temperature range. 


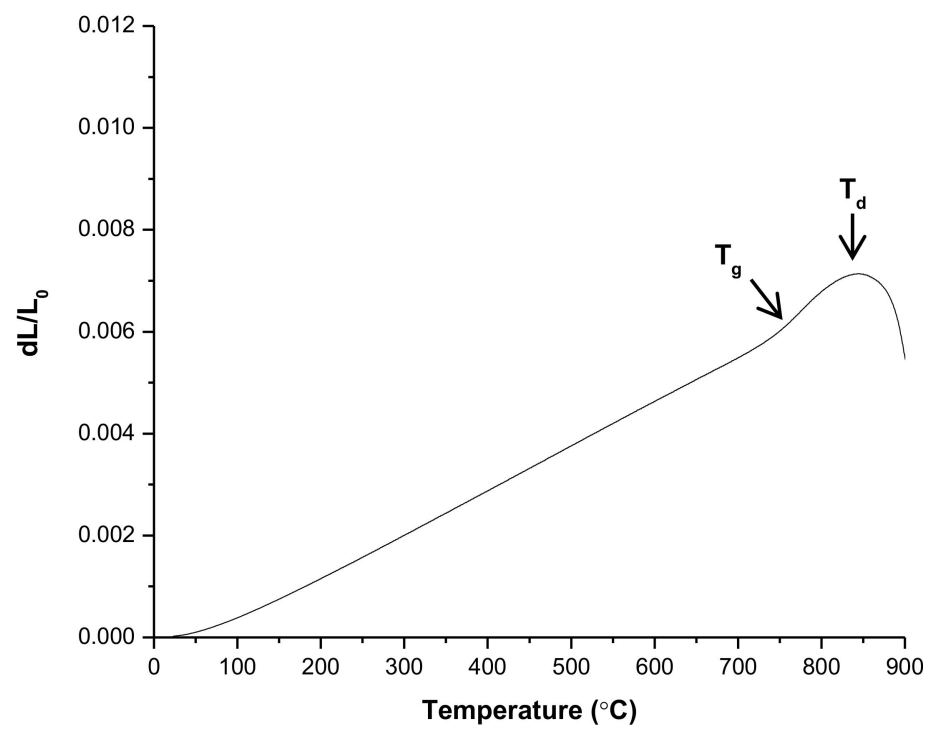

Figure 10. Dilatometric thermal expansion curve on heating for the volcanic ash glass at a heating rate of $5{ }^{\circ} \mathrm{C} / \mathrm{min}$ in air. Glass transition temperature $\left(T_{\mathrm{g}}\right)$ and glass softening temperature $\left(T_{\mathrm{d}}\right)$ are indicated.

Table 5. Thermal and mechanical properties of volcanic ash, synthetic sand, and desert sand glasses.

\begin{tabular}{cccc}
\hline Property & Volcanic Ash Glass & Synthetic Sand Glass * & Desert Sand Glass ${ }^{ \pm}$ \\
\hline Melting $\left(T_{\mathrm{m}},{ }^{\circ} \mathrm{C}\right)$ & $\sim 1300-1350{ }^{\circ} \mathrm{C}$ & 1176 & - \\
Density $\left(\mathrm{g} / \mathrm{cm}^{3}\right)$ & 2.52 & 2.63 & 2.69 \\
Glass transition temperature $\left(T_{\mathrm{g}},{ }^{\circ} \mathrm{C}\right)$ & 741 & 694 & 706 \\
Dilatometric softening point $\left(T_{\mathrm{d}},{ }^{\circ} \mathrm{C}\right)$ & 844 & 751 & 764 \\
Coefficient of thermal expansion $\left(\mathrm{CTE} \alpha, \mathrm{K}^{-1}\right)$ & $7.00 \times 10^{-6}$ & $9.32 \times 10^{-6}$ & $9.8 \times 10^{-6}$ \\
Young's Modulus $(E, \mathrm{GPa})$ & $\left(\sim 25-720^{\circ} \mathrm{C}\right)$ & $\left(\sim 25-690^{\circ} \mathrm{C}\right)$ & $\left(\sim 25-700^{\circ} \mathrm{C}\right)$ \\
Poisson's ratio $(v)$ & 75 & 84.3 & 92.3 \\
\end{tabular}

${ }^{*}$ Values obtained from $[17,18] ;{ }^{ \pm}$Values obtained from [19].

\subsection{Density and Mechanical Properties}

The bulk density, Elastic Modulus $(E)$, Poisson's ratio $(v)$, Vickers hardness $\left(H_{\mathrm{V}}\right)$, and indentation fracture toughness (evaluated by three different equations) for the volcanic ash glass are reported in Tables 5 and 6 . Density was found to be $2.52 \mathrm{~g} \mathrm{~cm}^{-3}$ and $\mathrm{E}$ and $v$ to be $75 \mathrm{GPa}$ and 0.24 , respectively. These values were comparable to those reported for the synthetic and desert sand glasses, though $\mathrm{E}$ for the synthetic and desert sand glasses was approximately 84 and $92 \mathrm{GPa}$, respectively, indicating that the volcanic ash glass was less stiff.

Vickers microhardness was determined at each load using the following equation [21]:

$$
H_{\mathrm{V}}=1.8544\left[\frac{P}{(2 a)^{2}}\right]
$$

where $P$ was the applied load and $2 a$ was the indentation diagonal length. Vickers hardness values determined at loads of $1.96,2.94,4.9$, and $9.8 \mathrm{~N}$ are reported in Table 6.

Indentation fracture toughness $\left(K_{C}\right)$ of the volcanic ash glass was calculated from indentation load and crack and diagonal lengths using relationships found in the literature. Miyoshi et al. [26] used the following:

$$
K_{\mathrm{C}}=0.026 a E^{0.5} P^{0.5} c^{-1.5}
$$

where $E$ was the Young's Modulus, $P$ was the indentation load, and $a$ and $c$ were half the indent length and crack length, respectively. Marshall and Evans [27] evaluated indentation fracture toughness using the following relation:

$$
K_{\mathrm{C}}=0.036 E^{0.4} P^{0.6} a^{0.8} c^{-1.5}
$$


Anstis et al. [28] presented:

$$
K_{\mathrm{C}}=(0.016 \pm 0.004) P\left(\frac{E}{H_{\mathrm{V}}}\right)^{0.5} c^{-1.5}
$$

to determine the indentation fracture toughness of glass specimens. $K_{C}$ values calculated using Equations (4)-(6) can be found in Table 6 for a range of indentation loads. The loads were chosen to prevent spalling while giving a reasonably long crack $(c>2 a)$. The hardness values for the volcanic ash glass are comparable to those of the synthetic and desert sand glasses, but the volcanic ash glass is significantly tougher $(\sim 1-2 \mathrm{MPa} \sqrt{ } \mathrm{m})$. The toughness of the synthetic and desert sand glasses is akin to that of many glasses, however, that of the volcanic ash glass more closely matches a glass-ceramic [29]. Hot pressing the glass at $600{ }^{\circ} \mathrm{C}$ resulted in the crystallization of some $\mathrm{Fe}_{3} \mathrm{O}_{4}$ precipitates in the sample (data not shown), which may explain the increased toughness.

Table 6. Vickers hardness and indentation fracture toughness at various indent loads for the volcanic ash glass and synthetic sand and desert sand glasses.

\begin{tabular}{|c|c|c|c|c|}
\hline \multirow[t]{2}{*}{ Indent Load, $P(\mathrm{~N})$} & \multirow[t]{2}{*}{ Vickers Hardness, $H_{V}(\mathrm{GPa})$} & \multicolumn{3}{|c|}{$\begin{array}{c}\text { Indentation Fracture Toughness, } K_{C}(\mathrm{MPa} \sqrt{ } \mathrm{m}) \text { Calculated Using } \\
\text { Equations (3)-(5) }\end{array}$} \\
\hline & & Miyoshi et al. [26] & Marshall and Evans [27] & Anstis et al. [28] \\
\hline \multicolumn{5}{|c|}{ Volcanic ash glass (current study) } \\
\hline 1.96 & $7.02 \pm 0.48$ & $n / a$ & $n / a$ & $n / a$ \\
\hline 2.94 & $6.22 \pm 0.28$ & $1.60 \pm 0.24$ & $1.83 \pm 0.28$ & $1.43 \pm 0.22$ \\
\hline 4.9 & $6.99 \pm 0.35$ & $1.31 \pm 0.08$ & $1.53 \pm 0.09$ & $1.17 \pm 0.07$ \\
\hline 9.8 & $7.03 \pm 0.37$ & $1.26 \pm 0.13$ & $1.47 \pm 0.15$ & $1.12 \pm 0.12$ \\
\hline Grand mean & $6.75 \pm 0.40$ & $1.39 \pm 0.18$ & $1.61 \pm 0.19$ & $1.24 \pm 0.17$ \\
\hline \multicolumn{5}{|c|}{ Synthetic sand glass $[17,18]$} \\
\hline 1.96 & $6.12 \pm 0.19$ & $0.72 \pm 0.04$ & $0.82 \pm 0.04$ & $0.62 \pm 0.04$ \\
\hline 2.94 & $6.28 \pm 0.19$ & $0.74 \pm 0.05$ & $0.86 \pm 0.05$ & $0.68 \pm 0.04$ \\
\hline 4.9 & $6.04 \pm 0.18$ & $0.66 \pm 0.05$ & $0.74 \pm 0.05$ & 0.6 \\
\hline 9.8 & $6.12 \pm 0.13$ & $0.62 \pm 0.04$ & $0.72 \pm 0.04$ & $0.58 \pm 0.04$ \\
\hline Grand mean & $6.14 \pm 0.10$ & $0.69 \pm 0.06$ & $0.79 \pm 0.07$ & $0.62 \pm 0.04$ \\
\hline \multicolumn{5}{|l|}{ Desert sand glass [19] } \\
\hline 1.96 & $5.90 \pm 0.10$ & $0.70 \pm 0.03$ & $0.70 \pm 0.03$ & $0.60 \pm 0.03$ \\
\hline 2.94 & $6.60 \pm 0.10$ & $0.80 \pm 0.05$ & $0.90 \pm 0.10$ & $0.70 \pm 0.05$ \\
\hline 4.9 & $6.40 \pm 0.10$ & $0.75 \pm 0.05$ & $0.80 \pm 0.10$ & $0.65 \pm 0.05$ \\
\hline 9.8 & $6.20 \pm 0.10$ & $0.65 \pm 0.05$ & $0.70 \pm 0.10$ & $0.60 \pm 0.10$ \\
\hline Grand mean & $6.28 \pm 0.30$ & $0.73 \pm 0.06$ & $0.78 \pm 0.10$ & $0.64 \pm 0.05$ \\
\hline
\end{tabular}

\subsection{Viscosity}

Experimental viscosity values for the volcanic ash glass, obtained by both continuous cooling and isothermal holds, are plotted in Figure 11 as a function of temperature. EDS analysis of the glass following viscosity testing suggested that the composition of the glass did not change during testing.

The experimental viscosities range from 15-105 Pa.s (log values 1.25-2) with a decreasing temperature. These values are considerably lower than expected from model predictions. Glass viscosity was predicted using three different viscosity models (Giordano et al., Fluegel, and the FactSage Viscosity Module with Melt Database). The Giordano et al. model [30] calculates the non-Arrhenian temperature dependence of viscosity for naturally occurring silicate melts by connecting experimentally obtained viscosity profiles with VFT (Vogel-Fulcher-Tamman) constants. The VFT equation is given by [31-33]

$$
\log \eta=A+\frac{B}{T-C}
$$

where A, B, and C are constants. The Fluegel model [34] also correlates VFT constants to experimental viscosity data, but for commercial silicate-based glasses. On the other hand, the FactSage method [25] 
of calculation is non-empirical, instead relating viscosity to melt structure. The Modified Quasichemical Model is utilized, along with thermodynamic values, to calculate viscosity for a given composition. The viscosity, based off of the Giordano et al., Fluegel, and FactSage models, is given as a function of temperature for the volcanic ash glass in Figure 11, alongside experimental values. It is assumed that the glass is fully molten at temperatures $1325-1500^{\circ} \mathrm{C}$ based on the results discussed previously.

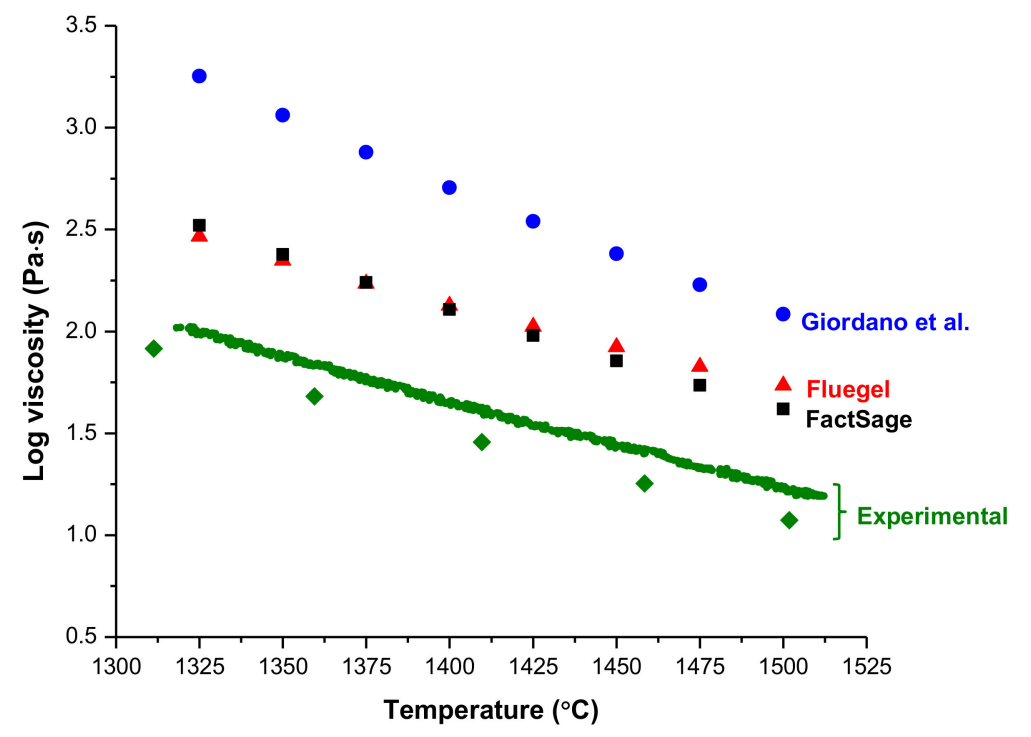

Figure 11. Viscosity curves for the volcanic ash glass used in this study based on experimental and calculated values. Calculated values were determined using the FactSage Viscosity Module and Melt Database (black squares), the Giordano et al. model (blue circles), and the Fluegel model (red triangles). Experimental data are given in green. The continuous curve is for the experimental method in which the glass was cooled at a constant $2{ }^{\circ} \mathrm{C} / \mathrm{min}$ while the separate diamond-shaped data points are for the experimental method in which the glass was equilibrated at $50{ }^{\circ} \mathrm{C}$ intervals.

It can be seen from Figure 11 that the FactSage and Fluegel models give values that are in good agreement, while the Giordano model viscosity is greater by up to about one order of magnitude. Wiesner et al. performed similar calculations on the synthetic sand glass composition given in Table 1 and also saw that the FactSage and Fluegel models showed reasonable agreement. Experimental measurements confirmed that the FactSage and Fluegel models were more accurate than the Giordano et al. model for that particular composition [35,36]. This result did not translate to the volcanic ash glass, which had an experimental viscosity lower than the FactSage and Fluegel models by about half an order of magnitude.

It is important to note that the input composition for the Giordano model is slightly different from that reported in Table 1 due to model constraints-notably, that the input was $\mathrm{FeO}$ instead of $\mathrm{Fe}_{2} \mathrm{O}_{3}$. The composition of the glass for this model was 5.1CaO-2.5MgO-15.2 $\mathrm{Al}_{2} \mathrm{O}_{3}-59.9 \mathrm{SiO}_{2}-9.3 \mathrm{FeO}-1.7 \mathrm{TiO}_{2}-4.6 \mathrm{Na}_{2} \mathrm{O}-1.7 \mathrm{~K}_{2} \mathrm{O}$ (wt \%). The $\mathrm{Fe}_{2} \mathrm{O}_{3}$ reported in Table 1 was converted to $\mathrm{FeO}$ (assuming $2 \mathrm{~mol} \mathrm{FeO}$ for $1 \mathrm{~mol} \mathrm{Fe}_{2} \mathrm{O}_{3}$ based on $\mathrm{Fe}$ alone) and trace oxides were not taken into account due to their total weight being unknown.

Wiesner and Bansal [18] estimated the amount of time (t) it would take for their synthetic sand CMAS to infiltrate a $200 \mu \mathrm{m}$ TBC, barring CMAS crystallization and/or other thermochemical interactions with the coating, using the following

$$
t \sim\left[\frac{k_{\mathrm{t}}}{8 D_{\mathrm{c}}}\left(\frac{1-\omega}{\omega}\right)^{2} L^{2}\right] \frac{\eta}{\sigma_{\mathrm{LV}}}
$$

where a tortuosity $\left(k_{\mathrm{t}}\right)$ value of $\sim 3$ was considered for the coating [5], the capillary diameter $\left(D_{\mathrm{c}}\right)$ was $1 \mu \mathrm{m}$ [37], $\omega \approx 0.1$ was the pore fraction open to flow [37], and surface tension $\left(\sigma_{\mathrm{LV}}\right)$ was assumed to be 
$\sim 0.4 \mathrm{~J} \mathrm{~m}^{-2}$, calculated using an approach for silicate glass melts at $1400^{\circ} \mathrm{C}$ [38]. Assuming these values for the current system and using the viscosities calculated at $1400{ }^{\circ} \mathrm{C}$ by each model, the infiltration time was determined to be $\sim 29 \mathrm{~min}$ for the Giordano model and $\sim 7-8 \mathrm{~min}$ for both the FactSage and Fluegel models. These values are compared to the calculated infiltration times for the synthetic sand glass in Table 7. Given that the experimental viscosity for the volcanic ash glass is about half an order of magnitude less than that calculated by the FactSage and Fluegel approaches, the expected time to complete infiltration at $1400{ }^{\circ} \mathrm{C}$ is actually around $2 \mathrm{~min}$. Experimental viscosities and infiltration times at $\sim 1400{ }^{\circ} \mathrm{C}$ are also given in Table 7 for the volcanic ash glass and the synthetic sand glass reported previously [35].

Table 7. Viscosity ( $\eta$ ) values (in Pa.s) as a function of temperature, model, and glass composition. The predicted time to complete the infiltration of a $200 \mu \mathrm{m}$ thick thermal barrier coating (TBC) (dependent on viscosity) at $1400{ }^{\circ} \mathrm{C}$ is given for synthetic sand [35,36] and volcanic ash glasses. The expected infiltration time based on experimental viscosity data (using isothermal holds) is also given.

\begin{tabular}{|c|c|c|c|c|c|c|c|c|}
\hline & \multicolumn{4}{|c|}{ Synthetic Sand } & \multicolumn{4}{|c|}{ Volcanic Ash } \\
\hline & Giordano & Fluegel & FactSage & Experimental & Giordano & Fluegel & FactSage & Experimental \\
\hline$\eta 1300^{\circ} \mathrm{C}$ & 274.9 & 33.6 & 78.1 & $19.5\left(1318^{\circ} \mathrm{C}\right)$ & 2848 & 389 & 465 & $82.3\left(1311^{\circ} \mathrm{C}\right)$ \\
\hline$\eta 1400{ }^{\circ} \mathrm{C}$ & 70.3 & 11.5 & 19.6 & $7.1\left(1411^{\circ} \mathrm{C}\right)$ & 507.3 & 134.0 & 127.9 & $28.6\left(1410^{\circ} \mathrm{C}\right)$ \\
\hline$\eta 1500^{\circ} \mathrm{C}$ & 22.3 & 4.8 & 6.2 & $3.3\left(1519^{\circ} \mathrm{C}\right)$ & 121.4 & 54.4 & 41.7 & $11.8\left(1502^{\circ} \mathrm{C}\right)$ \\
\hline $\begin{array}{l}\text { Infiltration Time } \\
\quad\left(1400^{\circ} \mathrm{C}\right)\end{array}$ & $3.8 \mathrm{~min}$ & $n / a$ & $1.1 \mathrm{~min}$ & $0.41 \min \left(1411^{\circ} \mathrm{C}\right)$ & $29.2 \mathrm{~min}$ & $7.7 \mathrm{~min}$ & $7.3 \mathrm{~min}$ & $1.6 \min \left(1410^{\circ} \mathrm{C}\right)$ \\
\hline
\end{tabular}

\section{Discussion}

The crystallized phases observed in this study are similar to those reported elsewhere. Mechnich et al. previously investigated a synthetic volcanic ash glass, prepared by sol-gel, with a composition approximating that of an actual Eyjafjallajökull deposit [39]. Calcination of the base glass powder at $800{ }^{\circ} \mathrm{C}$ resulted in the formation of $\mathrm{Fe}_{2} \mathrm{O}_{3}$, as well as some pseudobrookite $\left(\mathrm{Fe}_{2} \mathrm{TiO}_{5}\right)$ and aegirine $\left(\mathrm{NaFeSi}_{2} \mathrm{O}_{6}\right)$, within the glass. After heat treatment of a powdered mixture of the volcanic ash glass with TBC yttria-stabilized zirconia (YSZ) at temperatures of $900-1200{ }^{\circ} \mathrm{C}$, the hematite phase was still discerned and plagioclase was evident $\geq 1000{ }^{\circ} \mathrm{C}$. An electron beam-physical vapor deposited (EB-PVD) YSZ coating exposed to the glass for $1 \mathrm{~h}$ at $1200^{\circ} \mathrm{C}$ also showed the formation of plagioclase and an Fe-rich oxide at its surface. Jang et al. characterized an as-received volcanic ash deposit from the Eyjafjallajökull 2010 eruption and determined the presence of anorthite/albite (plagioclase), augite $\left(\mathrm{Ca}(\mathrm{Mg}, \mathrm{Fe}, \mathrm{Al})(\mathrm{Si}, \mathrm{Al})_{2} \mathrm{O}_{6}\right)$, and analcime $\left(\mathrm{Na}\left(\mathrm{Al}_{1}, \mathrm{Si}_{2} \mathrm{O}_{6}\right) \mathrm{H}_{2} \mathrm{O}\right)$ [40]. Interestingly, they did not report any Fe-based phases in the as-received sample despite it being composed of nearly $10 \mathrm{wt} \% \mathrm{Fe}_{2} \mathrm{O}_{3}$. The heat treatment history of their sample is unknown.

The volcanic ash glass showed considerably different crystallization behavior compared to a previously investigated synthetic sand glass (Table 1). Wiesner and Bansal [17] saw the formation of wollastonite $\left(\mathrm{CaSiO}_{3}\right)$ and aluminum diopside $\left(\mathrm{Ca}(\mathrm{Mg}, \mathrm{Al})(\mathrm{Si}, \mathrm{Al})_{2} \mathrm{O}_{6}\right)$ in bulk CMAS samples at temperatures as low as $925^{\circ} \mathrm{C}$. For the glass in this study, while DTA indicated crystallization at $900{ }^{\circ} \mathrm{C}$, and FactSage calculations suggested the same, furnace tests revealed that only a very small amount of $\mathrm{Fe}_{3} \mathrm{O}_{4}$ formed at this temperature. The synthetic sand CMAS glass was fully crystalline after $20 \mathrm{~h}$ at $925^{\circ} \mathrm{C}$ or $5 \mathrm{~h}$ at $960^{\circ} \mathrm{C}$. Based on the results of this study, it is clear that bulk volcanic ash glass pieces would not fully crystallize at these temperature/time scales. It is interesting to note that the powderized glass showed significantly increased crystallization kinetics (Table 4) compared to the bulk (Table 3) at 1100 and $1150{ }^{\circ} \mathrm{C}$. It is likely that the glass powder would also show increased crystallization at 900,1000 , and $1200^{\circ} \mathrm{C}$ compared to the bulk. It is possible, and apparently more desirable in terms of crystallization, that a protective coating $(\mathrm{T} / \mathrm{EBC})$ in service will come into contact with fine particles instead of bulk pieces.

Volcanic ash glass of this composition in contact with a T/EBC at temperatures nearing $1300{ }^{\circ} \mathrm{C}$ will likely soften/melt and penetrate the coating via defects such as open channels (in a TBC) or grain 
boundaries and pores/cracks (in an air plasma spray (APS)-deposited EBC). Barring any chemical interaction between the glass/coating, it is unlikely that infiltration will be halted by intrinsic glass crystallization, even with the assumption that there is a thermal gradient in the coating. A $250 \mu \mathrm{m}$ thick EB-PVD YSZ TBC was nearly completely infiltrated after only $1 \mathrm{~h}$ at $1200{ }^{\circ} \mathrm{C}$ in contact with an artificial volcanic ash glass [39]. Another study by Mechnich et al. investigated an alternative TBC material, $\mathrm{Gd}_{2} \mathrm{Zr}_{2} \mathrm{O}_{7}(\mathrm{GZO})$, in contact with the artificial volcanic ash and saw slowed infiltration (50 $\mu \mathrm{m}$ after $1 \mathrm{~h}$ at $1200^{\circ} \mathrm{C}$ ) compared to YSZ [41]. This slowing was likely due to the dissolution of the coating in the glass to form newly crystallized reaction products, including an oxyapatite phase, $\mathrm{Ca}_{2} \mathrm{Gd}_{8}\left(\mathrm{SiO}_{4}\right)_{6} \mathrm{O}_{2}$. In the study by Jang et al., the authors investigated the reaction between volcanic ash and a dense $\mathrm{EBC}$ material, $\mathrm{Yb}_{2} \mathrm{SiO}_{5}$, at $1400{ }^{\circ} \mathrm{C}$ [40]. Infiltration was halted by the formation of a thin layer of $\mathrm{Yb}_{2} \mathrm{Si}_{2} \mathrm{O}_{7} . \mathrm{Yb}_{2} \mathrm{SiO}_{5}$, in contact with a CMAS composition more closely approximating that of the synthetic sand glass (Table 1 ; increased $\mathrm{CaO}$ content, decreased $\mathrm{SiO}_{2}$ content), formed a much thicker reaction layer containing $\mathrm{Yb}$ apatite, $\mathrm{Ca}_{2} \mathrm{Yb}_{8}\left(\mathrm{SiO}_{4}\right)_{6} \mathrm{O}_{2}$.

TBC materials YSZ and GZO have higher CTEs than the bulk volcanic ash glass, with values of 11-12 [42,43]. If a TBC is infiltrated and then cooled, strain from a thermal mismatch between the coating and glass can lead to cracking and delamination. EBC materials, rare earth monosilicates $\left(\mathrm{Y}_{2} \mathrm{SiO}_{5}, \mathrm{Yb}_{2} \mathrm{SiO}_{5}\right)$, have CTEs $\sim 6-7.5[6,44,45]$, which are similar to that of the bulk volcanic ash glass. These materials, however, will have a relatively high thermal mismatch with an underlying SiC-based CMC. SiC has a CTE of about 4.5-5.5 $\times 10^{-6}{ }^{\circ} \mathrm{C}^{-6}$ [6]. Other proposed EBC materials, rare earth (RE) disilicates $\left(\mathrm{Y}_{2} \mathrm{Si}_{2} \mathrm{O}_{7}, \mathrm{Yb}_{2} \mathrm{Si}_{2} \mathrm{O}_{7}\right)$, have CTEs that more closely match that of SiC, ranging $\sim 3.5-5 \times 10^{-6}{ }^{\circ} \mathrm{C}^{-6}[46,47]$. The $\mathrm{CTE}$ of the bulk glass is greater than that of the $\mathrm{CMC} /$ disilicate system and the CTEs of the intrinsically crystallized phases in the glass are considerably so. CTE values (to $1000{ }^{\circ} \mathrm{C}$ ) for the crystalline products of $\mathrm{Fe}_{3} \mathrm{O}_{4}$ and $\mathrm{Fe}_{2} \mathrm{O}_{3}$ are around $9-15$ and $9-12 \times 10^{-6} \mathrm{~K}^{-1}$ [48], respectively, and 3 and $1.5 \times 10^{-5} \mathrm{~K}^{-1}$ for albite and anorthite, respectively [49]. Similar to that expected in a TBC system, CTE mismatch between the glass/crystallized glass and an EBC will likely result in spallation at the coating/glass interface.

In addition to CTE, mechanical properties such as elastic modulus, hardness, and toughness of the coated CMC can be compromised by CMAS attack. The bulk elastic moduli of TBC materials YSZ and GZO are on the order of 200-250 GPa [42,50-52]. However, the typical in-plane modulus for an EB-PVD TBC is about $30 \mathrm{GPa}$ [13]. Upon infiltration, the coating is stiffened, with an E reaching at least that of the glass (75 GPa), and the in-plane compliance of the TBC is degraded [13]. For current EBCs of $\gamma-\mathrm{Y}_{2} \mathrm{Si}_{2} \mathrm{O}_{7}$ and $\beta-\mathrm{Yb}_{2} \mathrm{Si}_{2} \mathrm{O}_{7}, \mathrm{E}$ is around 155 and $168 \mathrm{GPa}[53,54]$, respectively, while $\mathrm{Y}_{2} \mathrm{SiO}_{5}$ and $\mathrm{Yb}_{2} \mathrm{SiO}_{5}$ have values of 123 and $149 \mathrm{GPa}$, respectively [55,56]. The effect of changes in the elastic modulus is likely not as important in EBCs because they are relatively dense compared to TBCs.

Hardness and toughness values for YSZ and GZO are between 12-14 and 1-2, respectively [50,52]. The hardness of the volcanic ash glass is much lower than these TBC materials, while the toughness is similar. For the $\mathrm{Yb}$ - and $\mathrm{Y}$-based silicates, $\mathrm{H}_{\mathrm{V}}$ and $K_{\mathrm{C}}$ values are 6.4 and 2.3, respectively, for $\mathrm{Yb}_{2} \mathrm{SiO}_{5}$ [56], 7.3 and 2.8 for $\mathrm{Yb}_{2} \mathrm{Si}_{2} \mathrm{O}_{7}$ [54], 5.3 and 2.2 for $\mathrm{Y}_{2} \mathrm{SiO}_{5}$ [55], and 6.2 and 2.1 for $\mathrm{Y}_{2} \mathrm{Si}_{2} \mathrm{O}_{7}$ [53]. Hardness values reported here for the solidified volcanic ash are on the order of those for the RE silicates; more concerning is the apparent decrease in toughness, which could lead to diminished resistance of the coating to fracture due to CMAS infiltration. It is noted that the volcanic ash glass has a greater toughness than that reported for the synthetic and desert sand glasses.

The viscosity of the volcanic ash glass determined experimentally in this study was much lower than predicted by model calculations. Wiesner et al. reported that the FactSage and Fluegel models better represented experimental viscosity values for the synthetic sand glass composition (Table 1) than the Giordano et al. model $[35,36]$. While the FactSage and Fluegel model predictions more closely matched experimental data for the volcanic ash glass, compared to the Giordano et al. model, they were still higher by about half an order of magnitude. Preliminary Fourier-transform infrared spectroscopy (FTIR) measurements on the volcanic ash glass suggest that $\mathrm{H}_{2} \mathrm{O}$ was incorporated into its structure. The presence of water in glass can significantly lower glass viscosity [57], which is a 
possible explanation for the lower measured viscosity values. It is important to consider the effect of glass bonding with water when modeling CMAS viscosity, especially when considering an actual engine environment wherein high water vapor partial pressures are expected. It is also possible that none of the models investigated are adequate to describe viscosity for this particular composition. Additionally, the valence state of Fe in the glass is uncertain and can vary as a function of composition, temperature and $\mathrm{pO}_{2}$, and its role in the glass structure. The valence state's effect on glass structure is related to the overall viscosity of the melt. The available iron oxide inputs for the Fluegel and Giordano et al. models are limited to $\mathrm{Fe}_{2} \mathrm{O}_{3}$ and $\mathrm{FeO}$, respectively. The FactSage model can incorporate both $\mathrm{Fe}_{2} \mathrm{O}_{3}$ and $\mathrm{FeO}$ as input compositions. When substituting $\mathrm{FeO}$ for $\mathrm{Fe}_{2} \mathrm{O}_{3}$ in the volcanic ash glass composition given by Table 1, the predicted viscosity was lower (Table 8), but not to the degree given by experimental data. It is proposed that all $\mathrm{Fe}^{2+}$ acts as a glass network modifier while $\mathrm{Fe}^{3+}$ acts as a network former when $\mathrm{Fe}^{3+}: \mathrm{Fe}^{2+}>1$ [58], explaining the observed changes in calculated viscosity.

Table 8. Model FactSage viscosity ( $\eta$ ) values using $\mathrm{Fe}_{2} \mathrm{O}_{3}$ or $\mathrm{FeO}$ as inputs. Using $\mathrm{FeO}$ in place of $\mathrm{Fe}_{2} \mathrm{O}_{3}$, the composition was the same as that for the Giordano et al. model (5.1CaO-2.5MgO- $15.2 \mathrm{Al}_{2} \mathrm{O}_{3}-59.9 \mathrm{SiO}_{2}-9.3 \mathrm{FeO}-1.7 \mathrm{TiO}_{2}-4.6 \mathrm{Na}_{2} \mathrm{O}-1.7 \mathrm{~K}_{2} \mathrm{O}$ wt \%).

\begin{tabular}{ccc}
\hline Temperature $\left({ }^{\circ} \mathrm{C}\right)$ & Log $(\mathbf{P a} \cdot \mathbf{s})$ Using $\mathrm{Fe}_{2} \mathrm{O}_{3}$ & $\log \eta(\mathbf{P a} \cdot \mathbf{s})$ Using FeO \\
\hline 1500 & 1.62 & 1.44 \\
1475 & 1.74 & 1.55 \\
1450 & 1.85 & 1.66 \\
1425 & 1.98 & 1.78 \\
1400 & 2.11 & 1.90 \\
1375 & 2.24 & 2.03 \\
1350 & 2.38 & 2.16 \\
1325 & 2.52 & 2.30 \\
\hline
\end{tabular}

The infiltration times calculated for the synthetic sand glass and the volcanic ash glass determined from experimental viscosity values are not very different. The expected time to complete infiltration (determined using Equation (7) and experimental viscosity values; Table 7) is only slightly longer for coatings exposed to the volcanic ash glass $\left(1.6 \mathrm{~min}\right.$ at $\left.1410^{\circ} \mathrm{C}\right)$ compared to the synthetic sand glass $\left(0.41 \mathrm{~min}\right.$ at $\left.1411^{\circ} \mathrm{C}\right)$. This small difference in infiltration time is likely due to a slightly higher viscosity of the volcanic ash glass resulting in part from a greater $\mathrm{SiO}_{2}$ and lesser $\mathrm{CaO}$ content.

Equation (7) has limitations in its ability to predict the infiltration rate in T/EBCs. The competing effect of crystallization in the determination of infiltration time should be considered for a TBC such as GZO. This coating material dissolves to some degree in contact with CMAS and contributes metal ions to the melt, inducing crystallization of oxyapatite. In addition, this equation is not well suited to predict infiltration in APS-deposited EBCs. APS EBCs are nominally dense and do not contain open channels for CMAS to penetrate (although grain boundaries and pores are susceptible). However, regardless of type, a coating material that reacts quickly with the volcanic ash glass to form newly crystallized phases will likely slow penetration. The low viscosities (Table 7) and sluggish crystallization reported for the volcanic ash glass studied here can lead to fast infiltration via coating channels and defects.

\section{Summary and Conclusions}

The intrinsic thermal and mechanical properties of a volcanic ash glass were studied using a variety of characterization techniques. It was determined that the glass had a low propensity to crystallize in bulk form, with $\leq 20 \mathrm{wt} \%$ transforming to $\mathrm{Fe}_{3} \mathrm{O}_{4}, \mathrm{Fe}_{2} \mathrm{O}_{3}$, and/or plagioclase after up to $40 \mathrm{~h}$ at temperatures of $900-1200{ }^{\circ} \mathrm{C}$. This was in contrast to a previously investigated synthetic sand glass, which was more easily able to crystallize and formed wollastonite $\left(\mathrm{CaSiO}_{3}\right)$ and diopside $\left(\mathrm{Ca}(\mathrm{Mg}, \mathrm{Al})(\mathrm{Si}, \mathrm{Al})_{2} \mathrm{O}_{6}\right)$. The ability of the volcanic ash glass to crystallize was improved when exposed in powder form. 
The melting temperature $\left(T_{\mathrm{m}}\right)$, glass transition temperature $\left(T_{\mathrm{g}}\right)$, and glass softening temperature $\left(T_{\mathrm{d}}\right)$ of the volcanic ash glass were greater than those of sand glass compositions. There was a broad melting range for the volcanic ash glass, determined by DTA; after heating to $1300^{\circ} \mathrm{C}$ at $10{ }^{\circ} \mathrm{C} / \mathrm{min}$ and quenching in air, the glass was mostly amorphous by XRD analysis. The coefficient of thermal expansion (CTE) and Young's modulus $(E)$ of the volcanic ash glass were lower than those reported for sand glasses. Hardness values were similar, but the indentation fracture toughness of the volcanic ash glass was about twice that of the sand glasses, likely due to the presence of some $\mathrm{Fe}_{3} \mathrm{O}_{4}$ crystallites in the tested sample.

The viscosity of the volcanic ash glass was lower than expected from model predictions. This is unlike that reported for the synthetic sand glass composition, which showed relatively good agreement with Fluegel and FactSage viscosity models. The discrepancies in this study could be due to the difference in the glass composition, or possibly the incorporation of water in the volcanic ash glass structure. Experimental viscosities for the volcanic ash glass were higher than for the synthetic sand glass, in part likely due to a greater $\mathrm{SiO}_{2}$ and lesser $\mathrm{CaO}$ content.

In conclusion, it has been shown that the chemical and mechanical properties of the Eyjafjallajökull volcanic ash CMAS glass can vary significantly from sand-based CMAS glass compositions. In assessing the potential of new coating (T/EBCs) materials for use over a wide range of operating conditions, the variation of CMAS properties with composition must be understood.

Author Contributions: Conceptualization, V.L.W.; methodology, V.L.W. and R.I.W.; validation, V.L.W., J.A.S. and N.P.B.; formal analysis, R.I.W.; investigation, R.I.W.; resources, V.L.W., J.A.S., N.P.B. and E.J.O.; data curation, V.L.W., J.A.S., N.P.B. and R.I.W.; writing—original draft preparation, R.I.W.; writing—review and editing, V.L.W., J.A.S., N.P.B. and E.J.O.; visualization, V.L.W.; supervision, V.L.W., J.A.S. and N.P.B.; project administration, V.L.W.; funding acquisition, V.L.W. and E.J.O. All authors have read and agree to the published version of the manuscript.

Funding: This research was supported by NASA's Transformative Tools and Technologies (TTT) Project within the Transformative Aeronautics Concept Program (TCAP) and the Lewis' Educational and Research Collaborative Internship Project (LERCIP) at NASA Glenn Research Center.

Acknowledgments: The authors are grateful to Gustavo Costa, Bryan Harder, Nathan Jacobson, Dereck Johnson, and Richard Rogers for training and helpful discussion, and Marie Kløve Keiding, Magnus Gudmundsson, and Tinna Jónsdóttir for assistance in obtaining volcanic ash from the Eyjafjallajökull eruption used in this study.

Conflicts of Interest: The authors declare no conflict of interest.

\section{References}

1. De Wet, D.; Taylor, R.; Stott, F. Corrosion mechanisms of $\mathrm{ZrO}_{2}-\mathrm{Y}_{2} \mathrm{O}_{3}$ thermal barrier coatings in the presence of molten middle-east sand. J. Phys. IV 1993, 3, 655-663. [CrossRef]

2. Stott, F.H.; De Wet, D.; Taylor, R. Degradation of thermal barrier coatings at very high temperature. MRS Bull. 1994, 19, 46-49. [CrossRef]

3. Clarke, D.R.; Oechsner, M.; Padture, N.P. Thermal-barrier coatings for more efficient gas turbine engines. MRS Bull. 2012, 37, 891-898. [CrossRef]

4. Ohnabe, H.; Masaki, S.; Onozuka, M.; Miyahara, K.; Sasa, T. Potential application of ceramic matrix composites to aero-engine components. Compos. Part A 1999, 30, 489-496. [CrossRef]

5. Lee, K.N. Environmental Barrier Coatings for $\mathrm{SiC}_{\mathrm{f}} / \mathrm{SiC}$. In Ceramic Matrix Composites: Materials, Modeling and Technology; Bansal, N.P., Lamon, J., Eds.; John Wiley and Sons: Hoboken, NJ, USA, 2014; pp. 430-451.

6. Lee, K.N.; Fox, D.S.; Bansal, N.P. Rare earth silicate environmental barrier coatings for SiC/SiC composites and $\mathrm{Si}_{3} \mathrm{~N}_{4}$ ceramics. J. Eur. Ceram. Soc. 2005, 25, 1705-1715. [CrossRef]

7. Borom, M.P.; Johnson, C.A.; Peluso, L.A. Role of environment deposits and operating surface temperature in spallation of air plasma sprayed thermal barrier coatings. Surf. Coat. Technol. 1996, 86, 116-126. [CrossRef]

8. Krämer, S.; Yang, J.; Levi, C.G. Infiltration-inhibiting reaction of gadolinium zirconate thermal barrier coatings with CMAS melts. J. Am. Ceram. Soc. 2008, 91, 576-583. [CrossRef]

9. Poerschke, D.L.; Jackson, R.W.; Levi, C.G. Silicate deposit degradation of engineered coatings in gas turbines: Progress toward models and materials solutions. Annu. Rev. Mater. Res. 2017, 47, 297-330. [CrossRef] 
10. Stolzenburg, F.; Johnson, M.T.; Lee, K.N.; Jacobson, N.S.; Faber, K.T. The interaction of calcium magnesium-aluminosilicate with ytterbium silicate environmental barrier materials. Surf. Coat. Technol. 2015, 284, 44-50. [CrossRef]

11. Zhao, H.; Richards, B.T.; Levi, C.G.; Wadley, H.N.G. Molten silicate reactions with plasma sprayed ytterbium silicate coatings. Surf. Coat. Technol. 2016, 288, 151-162. [CrossRef]

12. Ahlborg, N.L.; Zhu, D. Calcium-magnesium aluminosilicate (CMAS) reactions and degradation mechanisms of advanced environmental barrier coatings. Surf. Coat. Technol. 2013, 237, 79-87. [CrossRef]

13. Wiesner, V.L.; Harder, B.J.; Bansal, N.P. High-temperature interactions of desert sand CMAS glass with yttrium disilicate environmental barrier coating material. Ceram. Int. 2018, 44, 22738-22743. [CrossRef]

14. Levi, C.G.; Hutchinson, J.W.; Vidal-Sétif, M.-H.; Johnson, C.A. Environmental degradation of thermal barrier coatings by molten deposits. MRS Bull. 2012, 37, 932-941. [CrossRef]

15. Zaleski, E.M.; Ensslen, C.; Levi, C.G. Melting and crystallization of silicate systems relevant to thermal barrier coating damage. J. Am. Ceram. Soc. 2015, 98, 1642-1649. [CrossRef]

16. Delmelle, P.; Lambert, M.; Dufrêne, Y.; Gerin, P.; Óskarsson, N. Gas/aerosol-ash interaction in volcanic plumes: New insights from surface analyses of fine ash particles. Earth Planet. Sci. Lett. 2007, 259, 159-170. [CrossRef]

17. Wiesner, V.L.; Bansal, N.P. Crystallization kinetics of calcium-magnesium aluminosilicate (CMAS) glass. Surf. Coat. Technol. 2014, 259, 608-615. [CrossRef]

18. Wiesner, V.L.; Bansal, N.P. Mechanical and thermal properties of calcium magnesium aluminosilicate (CMAS) glass. J. Eur. Ceram. Soc. 2015, 35, 2907-2914. [CrossRef]

19. Bansal, N.P.; Choi, S.R. Properties of CMAS glass from desert sand. Ceram. Int. 2015, 41, 3901-3909. [CrossRef]

20. ASTM C1259-14 Standard Test Method for Dynamic Young's Modulus, Shear Modulus, and Poisson's Ratio for Advanced Ceramics by Impulse Excitation of Vibration; ASTM International: Conshohocken, PA, USA, 2014.

21. ASTM C1327-08 Standard Test Method for Vickers Indentation Hardness of Advanced Ceramics; ASTM International: Conshohocken, PA, USA, 2008.

22. Lamkin, M.A.; Riley, F.L.; Fordham, R.J. Oxygen mobility in silicon dioxide and silicate glasses: A review. J. Eur. Ceram. Soc. 1992, 10, 347-367. [CrossRef]

23. Monazam, E.R.; Breault, R.W.; Siriwardane, R. Kinetics of magnetite $\left(\mathrm{Fe}_{3} \mathrm{O}_{4}\right)$ oxidation to hematite $\left(\mathrm{Fe}_{2} \mathrm{O}_{3}\right)$ in air for chemical looping combustion. Ind. Eng. Chem. Res. 2014, 53, 13320-13328. [CrossRef]

24. Forsmo, S.P.E.; Forsmo, S.-E.; Samskog, P.-O.; Björkman, B.M.T. Mechanisms in oxidation and sintering of magnetite iron ore green pellets. Powder Technol. 2008, 183, 247-259. [CrossRef]

25. Bale, C.W.; Bélisle, E.; Chartrand, P.; Decterov, S.A.; Eriksson, G.; Hack, K.; Jung, I.-H.; Kang, Y.B.; Melançon, J.; Pelton, A.D.; et al. FactSage thermochemical software and databases-recent developments. Calphad 2009, 33, 295-311. [CrossRef]

26. Miyoshi, T.; Sagawa, N.; Sassa, T. Study on fracture toughness evaluation for structural ceramics. Trans. Jpn. Soc. Mech. Eng. 1985, 51, 2487-2489. [CrossRef]

27. Marshall, D.; Evans, A. Reply to "Comment on 'Elastic/plastic indentation damage in ceramics: The median/radial crack system'”. J. Am. Ceram. Soc. 1981, 64, C182-C183.

28. Anstis, G.; Chantikul, P.; Lawn, B.R.; Marshall, R. A critical evaluation of indentation techniques for measuring fracture toughness: I. Direct crack measurements. J. Am. Ceram. Soc. 1981, 64, 533-538. [CrossRef]

29. Salem, J.; Jenkins, M. Applying ASTM International C1421 to glasses and optical ceramics. In Proceedings of the 42nd International Conference on Advanced Ceramics and Composites, Ceramic Engineering and Science Proceedings; Salem, J., Koch, D., Mechnich, P., Kusnezoff, M., Bansal, N.P., LaSalvia, J.C., Balaya, P., Fu, Z., Ohii, T., Wiesner, V., et al., Eds.; John Wiley \& Sons: Hoboken, NJ, USA, 2019; Volume 39, pp. 27-40.

30. Giordano, D.; Russell, J.K.; Dingwell, D.B. Viscosity of magmatic liquids: A model. Earth Planet. Sci. Lett. 2008, 271, 123-134. [CrossRef]

31. Vogel, D.H. Temperaturabhängigkeitsgesetz der Viskosität von Flüssigkeiten. Phys. Z. 1921, 22, $645-646$.

32. Fulcher, G.S. Analysis of recent measurements of the viscosity of glasses. J. Am. Ceram. Soc. 1925, 8, 339-355. [CrossRef]

33. Tammann, G.; Hesse, W. Die abhängigkeit der viskosität von der temperatur bei unterkühlten flüssigkeiten. Z. Anorgan. Allg. Chem. 1926, 156, 245-257. [CrossRef] 
34. Fluegel, A. Glass viscosity calculation based on a global statistical modeling approach. Glass Technol. Eur. J. Glass Sci. Technol. Part A 2007, 48, 13-30.

35. Wiesner, V.L.; Vempati, U.K.; Bansal, N.P. High temperature viscosity of calcium magnesium aluminosilicate glass from synthetic sand. Scr. Mater. 2016, 124, 189-192. [CrossRef]

36. Wiesner, V.L.; Vempati, U.K.; Bansal, N.P. Corrigendum to "High temperature viscosity of calcium-magnesium-aluminosilicate glass from synthetic sand" [Scripta Mater. 2016, 124, 189-192]. Scr. Mater. 2017, 130, 298. [CrossRef]

37. Krämer, S.; Yang, J.; Levi, C.G.; Johnson, C.A. Thermochemical interaction of thermal barrier coatings with molten $\mathrm{CaO}-\mathrm{MgO}-\mathrm{Al}_{2} \mathrm{O}_{3}-\mathrm{SiO}_{2}$ (CMAS) deposits. J. Am. Ceram. Soc. 2006, 89, 3167-3175. [CrossRef]

38. Kucuk, A.; Clare, A.; Jones, L. An estimation of the surface tension for silicate glass melts at $1400{ }^{\circ} \mathrm{C}$ using statistical analysis. Glass Technol. 1999, 40, 149-153.

39. Mechnich, P.; Braue, W.; Schulz, U. High-temperature corrosion of EB-PVD yttria partially stabilized zirconia thermal barrier coatings with an artificial volcanic ash overlay. J. Am. Ceram. Soc. 2011, 94, 925-931. [CrossRef]

40. Jang, B.-K.; Feng, F.-J.; Suzuta, K.; Tanaka, H.; Matsushita, Y.; Lee, K.-S.; Ueno, S. Corrosion behavior of volcanic ash and calcium magnesium aluminosilicate on $\mathrm{Yb}_{2} \mathrm{SiO}_{5}$ environmental barrier coatings. J. Ceram. Soc. Jpn. 2017, 125, 326-332. [CrossRef]

41. Mechnich, P.; Braue, W. Volcanic ash-induced decomposition of EB-PVD Gd $\mathrm{Zr}_{2} \mathrm{O}_{7}$ thermal barrier coatings to Gd-oxyapatite, zircon, and Gd,Fe-zirconolite. J. Am. Ceram. Soc. 2013, 96, 1958-1965. [CrossRef]

42. Evans, A.G.; Mumm, D.R.; Hutchinson, J.W.; Meier, G.H.; Pettit, F.S. Mechanisms controlling the durability of thermal barrier coatings. Prog. Mater. Sci. 2001, 46, 505-553. [CrossRef]

43. Touloukian, Y.S.; Kirby, R.K.; Taylor, R.E.; Lee, T.Y.R. Thermal Expansion-Non Metallic Solids; IFI/Plenum: New York, NY, USA, 1977; Volume 13.

44. Fukuda, K.; Matsubara, H. Anisotropic thermal expansion in yttrium silicate. J. Mater. Res. 2003, 18, 1715-1722. [CrossRef]

45. NETL. The Gas Turbine Handbook; United States Department of Energy (DOE): Morgantown, WV, USA, 2006.

46. Sun, Z.; Zhou, Y.; Wang, J.; Li, M. Thermal properties and thermal shock resistance of $\gamma-\mathrm{Y}_{2} \mathrm{Si}_{2} \mathrm{O}_{7}$. J. Am. Ceram. Soc. 2008, 91, 2623-2629. [CrossRef]

47. Fernández-Carrión, A.J.; Allix, M.; Becerro, A.I. Thermal expansion of rare-earth pyrosilicates. J. Am. Ceram. Soc. 2013, 96, 2298-2305. [CrossRef]

48. Takeda, M.; Onishi, T.; Nakakubo, S.; Fujimoto, S. Physical properties of iron-oxide scales on Si containing steels at high temperature. Mater. Trans. 2009, 50, 2242-2246. [CrossRef]

49. Tribaudino, M.; Angel, R.J.; Cámara, F.; Nestola, F.; Pasqual, D.; Margiolaki, I. Thermal expansion of plagioclase feldspars. Mineral. Petrol. 2010, 160, 899-908. [CrossRef]

50. Vassen, R.; Cao, X.; Tietz, F.; Basu, D.; Stöver, D. Zirconates as new materials for thermal barrier coatings. J. Am. Ceram. Soc. 2000, 83, 2023-2028. [CrossRef]

51. Van Dijk, M.P.; de Vries, K.J.; Burggraaf, A.J. Oxygen ion and mixed conductivity in compounds with the fluorite and pyrochlore structure. Solid State Ion. 1983, 9-10, 913-919. [CrossRef]

52. Schmitt, M.P.; Stokes, J.L.; Gorin, B.L.; Rai, A.K.; Zhu, D.; Eden, T.J.; Wolfe, D.E. Effect of Gd content on mechanical properties and erosion durability of sub-stoichiometric $\mathrm{Gd}_{2} \mathrm{Zr}_{2} \mathrm{O}_{7}$. Surf. Coat. Technol. 2017, 313, 177-183. [CrossRef]

53. Sun, Z.; Zhou, Y.; Wang, J.; Li, M. $\gamma-\mathrm{Y}_{2} \mathrm{Si}_{2} \mathrm{O}_{7}$, a machinable silicate ceramic: Mechanical properties and machinability. J. Am. Ceram. Soc. 2007, 90, 2535-2541. [CrossRef]

54. Zhou, Y.-C.; Zhao, C.; Wang, F.; Sun, Y.-J.; Zheng, L.-Y.; Wang, X.-H. Theoretical prediction and experimental investigation on the thermal and mechanical properties of bulk $\beta-\mathrm{Yb}_{2} \mathrm{Si}_{2} \mathrm{O}_{7}$. J. Am. Ceram. Soc. 2013, 96, 3891-3900. [CrossRef]

55. Sun, Z.; Wang, J.; Li, M.; Zhou, Y. Mechanical properties and damage tolerance of $\mathrm{Y}_{2} \mathrm{SiO}_{5}$. J. Eur. Ceram. Soc. 2008, 28, 2895-2901. [CrossRef]

56. Lu, M.-H.; Xiang, H.-M.; Feng, Z.-H.; Wang, X.-Y.; Zhou, Y.-C. Mechanical and thermal properties of $\mathrm{Yb}_{2} \mathrm{SiO}_{5}$ : A promising material for T/EBCs applications. J. Am. Ceram. Soc. 2016, 99, 1401-1411. [CrossRef] 
57. Stolper, E. Water in silicate glasses: An infrared spectroscopic study. Contrib. Mineral. Petrol. 1982, 81, 1-17. [CrossRef]

58. Cook, G.B.; Cooper, R.F. Chemical diffusion and crystalline nucleation during oxidation of ferrous iron-bearing magnesium aluminosilicate glass. J. Non Cryst. Solids 1990, 120, 207-222. [CrossRef]

(C) 2020 by the authors. Licensee MDPI, Basel, Switzerland. This article is an open access article distributed under the terms and conditions of the Creative Commons Attribution (CC BY) license (http://creativecommons.org/licenses/by/4.0/). 